\title{
Air pollution during the 2003 European heat wave as seen by MOZAIC airliners
}

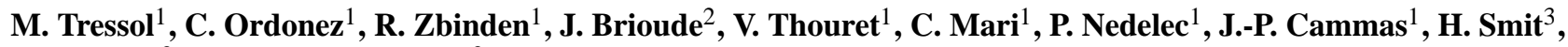 \\ H.-W. Patz ${ }^{3}$, and A. Volz-Thomas ${ }^{3}$ \\ ${ }^{1}$ Laboratoire d'Aérologie, UMR 5560, CNRS, Université de Toulouse, 14 Avenue E. Belin, 31400 Toulouse, France \\ ${ }^{2}$ Chemical Sciences Division, Earth System Research Laboratory, NOAA, Boulder, Colorado, USA \\ ${ }^{3}$ Institut für Chemie und Dynamik der Geosphäre II: Troposphäre, Forschungszentrum Jülich, Jülich, Germany
}

Received: 17 September 2007 - Published in Atmos. Chem. Phys. Discuss.: 13 November 2007

Revised: 4 March 2008 - Accepted: 14 March 2008 - Published: 15 April 2008

\begin{abstract}
This study presents an analysis of both MOZAIC profiles above Frankfurt and Lagrangian dispersion model simulations for the 2003 European heat wave. The comparison of MOZAIC measurements in summer 2003 with the 11-year MOZAIC climatology reflects strong temperature anomalies (exceeding $4^{\circ} \mathrm{C}$ ) throughout the lower troposphere. Higher positive anomalies of temperature and negative anomalies of both wind speed and relative humidity are found for the period defined here as the heat wave (2-14 August 2003), compared to the periods before (16-31 July 2003) and after (16-31 August 2003) the heat wave. In addition, Lagrangian model simulations in backward mode indicate the suppressed long-range transport in the mid- to lower troposphere and the enhanced southern origin of air masses for all tropospheric levels during the heat wave. Ozone and carbon monoxide also present strong anomalies (both $\sim+40$ ppbv) during the heat wave, with a maximum vertical extension reaching $6 \mathrm{~km}$ altitude around 11 August 2003. Pollution in the planetary boundary layer (PBL) is enhanced during the day, with ozone mixing ratios two times higher than climatological values. This is due to a combination of factors, such as high temperature and radiation, stagnation of air masses and weak dry deposition, which favour the accumulation of ozone precursors and the build-up of ozone. A negligible role of a stratospheric-origin ozone tracer has been found for the lower troposphere in this study. From 29 July to 15 August 2003 forest fires burnt around $0.3 \times 10^{6}$ ha in Portugal and added to atmospheric pollution in Europe. Layers with enhanced $\mathrm{CO}$ and $\mathrm{NO}_{\mathrm{y}}$ mixing ratios, advected from Portugal, were crossed by the MOZAIC aircraft in the free troposphere over Frankfurt. A series of forward and backward Lagrangian model simulations have been performed to investigate the origin of anomalies dur-
\end{abstract}

Correspondence to: $\mathrm{M}$. Tressol

(marc.tressol@aero.obs-mip.fr) ing the whole heat wave. European anthropogenic emissions present the strongest contribution to the measured $\mathrm{CO}$ levels in the lower troposphere (near 30\%). This source is followed by Portuguese forest fires which affect the lower troposphere after 6 August 2003 and even the PBL around 10 August 2003. The averaged biomass burning contribution reaches $35 \%$ during the affected period. Anthropogenic $\mathrm{CO}$ of North American origin only marginally influences $\mathrm{CO}$ levels over Europe during that period.

\section{Introduction}

Summer 2003 was one of the hottest in the history of Western Europe, with surface temperature exceeding by $2.4^{\circ} \mathrm{C}$ the average surface temperature reported for the 1901-1995 period (Luterbacher et al., 2004). Over Central Europe, the mean air temperature anomalies at $2 \mathrm{~m}$ for June to August 2003 with respect to the 1958-2001 period were maximum over France and the Alpine region, and they ranged from $3^{\circ} \mathrm{C}$ to $6^{\circ} \mathrm{C}$ (Grazzini et al., 2003). In France, observed average temperature in Paris for summer 2003 was $3.6^{\circ} \mathrm{C}$ above normal (Bessemoulin et al., 2004). Not only temperatures reached exceptional high levels, but also both the number of consecutive days during which temperatures exceeded the seasonal average and the spatial extent of the heat wave episode have never been reported before (Trigo et al., 2005). In August, the temperature increase peaked during the first two weeks due to a strong amplification of Rossby waves that reinforced the pre-existing anticyclone over Europe (Grazzini et al., 2003; Trigo et al., 2005). The long clear sky periods associated with the blocking conditions contributed to the increase in solar radiative heating over Europe (GarcíaHerrera et al., 2005). Anomalous anticyclonic conditions during summer led to an increase in the monthly mean daily

Published by Copernicus Publications on behalf of the European Geosciences Union. 
observed solar radiation at the ground of $1 \mathrm{kWh} \mathrm{m}^{-2}(+20 \%)$ with respect to the mean value for the 10 past years (Cros et al., 2004). Whether the nature of these anomalies is exceptional or whether it is a signal of changes in the climate distribution is still a debate. Recent studies based on regional climate modelling suggest that the summer 2003 could be a normal summer in the coming decades (Beniston, 2004; Schär et al., 2004). Based on meteorological records and mesoscale modelling, Vautard et al. (2007) emphasized the link between winter rainfall deficits in Southern Europe and the heat spreads northward throughout Europe in early summer.

Under extreme meteorological conditions of the 2003 heat wave, the chemical processes leading to ozone formation are perturbed compared to periods with more typical temperatures. The high temperature influences summer ozone because of its link with high radiation, stagnation of the air masses and thermal decomposition of peroxyacetylnitrate (PAN) (Sillman and Samson, 1995). Radiation favours photolysis of $\mathrm{NO}_{2}$, ozone and carbonyls yielding radical formation with subsequent involvement in ozone production. Stagnation of air masses allows the accumulation of pollutants in the planetary boundary layer (PBL) and in the residual layer during the night. Based on surface observations and trajectory analysis, Solberg et al. (2008) pointed out the impacts of these extremely high temperatures on air pollution and the extended residence time of the air parcels in the boundary layer, which are important factors for enhanced ozone production. Lee et al. (2006) established that the initial morning rises in ozone during the episode over London were caused by the collapse of the inversion layer and entrainment of air from aloft in the nocturnal residual layer polluted on a regional scale. Increased temperatures and solar radiation favoured biogenic emissions of isoprene with a potential for enhanced ozone chemistry in the boundary layer (Lee et al., 2006). High temperature and spring to summer precipitation deficit reduced ozone dry deposition (Vautard et al., 2005). All these processes favour the photochemical production of surface ozone and its accumulation. The differences in ozone concentrations during the heat wave period compared to the rest of August 2003 were confirmed by observations at surface European networks (Vautard et al., 2005; Solberg et al., 2008). Ozone concentration exceeded the public information threshold ( $1 \mathrm{~h}$ ozone concentration $>180 \mu \mathrm{g} \mathrm{m}^{-3}$ or $84 \mathrm{ppbv}$ ) in $86 \%$ of the French survey pollution network (Elichegaray et al., 2003) and in $68 \%$ of European stations (Fiala et al., 2003). In Switzerland, the measured daily ozone maximum was $15 \mathrm{ppbv}$ higher than in the reference period summer 1992-2002 (Ordonez et al., 2005). In addition, the high temperatures and exceptional drought led to extensive forest fires on the Iberian Peninsula (Elias et al., 2006; Lyamani et al., 2006a,b; Hodzic et al., 2006, 2007). Solberg et al. (2008) suggested that fires contributed to the peak of ozone ground value observed in Northern Europe in $\mathrm{Au}-$ gust 2003. Pace et al. (2005) used MODIS observations be- tween 2000 and 2004 to demonstrate that the summer 2003 forest fire aerosol episode was the longest and covered the largest area ever recorded. In a modelling study, wild fires caused an increase of $\mathrm{PM}_{10}$ over several regions in Europe by $3 \mu \mathrm{g} \mathrm{m}^{-3}$ to $5 \mu \mathrm{g} \mathrm{m}^{-3}$ for the Southern Mediterranean basin and the Benelux (Hodzic et al., 2007). The biomass burning aerosol layer in the mid troposphere was shown to produce a large increase in the heating rate of $2.8 \mathrm{~K} \mathrm{day}^{-1}$ at $20^{\circ}$ solar zenith angle within the biomass burning aerosol layer (Pace et al., 2005). Over Western Europe the smoke aerosol radiative forcing during August 2003 varies between $5 \mathrm{~W} \mathrm{~m}^{-2}$ and $25 \mathrm{~W} \mathrm{~m}^{-2}$ with the highest value in the presence of the smoke plume. Wildfire aerosols participate to increase the atmospheric stability and to enhance hot and dry conditions during summer 2003 (Pace et al., 2005; Hodzic et al., 2007).

The objective of this paper is to investigate for the first time the vertical extension and the origins of pollutants during the 2003 heat wave with a set of 162 profiles of ozone, carbon monoxide and relative humidity performed from 16 July to 31 August 2003 by 3 MOZAIC airliners over Frankfurt (Measurements of OZone, water vapour, carbon monoxide and nitrogen oxides by Airbus In-service airCraft, http:// mozaic.aero.obs-mip.fr/web/), (Marenco et al., 1998). First, the main characteristics and the anomalies of meteorological parameters (temperature, wind speed, relative humidity) and of reactive gas concentrations (ozone, carbon monoxide and total nitrogen oxide) in vertical profiles above Frankfurt are investigated in relation to the meteorological situation and to the climatology. Then a Lagrangian dispersive model is used to investigate the origins of the main anomalies of pollutants during the episode. Section 2 describes the methods and measurements used in this paper. The meteorological situation is described in Sect. 3. Based on MOZAIC measurements and back-trajectory calculations, a description of the vertical extension of chemical tracers is documented in Sect. 4 together with the investigation of their origins. Section 5 provides a discussion on the relative contribution of forest fires versus other anthropogenic emissions to the $\mathrm{CO}$ levels observed by the MOZAIC aircraft in Frankfurt.

\section{Method}

\subsection{MOZAIC measurements}

Five commercial airliners were equipped by the MOZAIC program (Marenco et al., 1998) with ozone $\left(\mathrm{O}_{3}\right)$ and relative humidity (RH) instruments since 1994 , and a carbon monoxide (CO) analyser was added in 2001. One aircraft carries an additional instrument to measure total odd nitrogen $\left(\mathrm{NO}_{\mathrm{y}}\right)$ since 2001 . Measurements are taken from takeoff to landing, except for $\mathrm{NO}_{\mathrm{y}}$ which is not measured in the lower troposphere during descents and in the whole troposphere during ascents. Based on the dual-beam UV absorption principle (Thermo-Electron, Model 49-103), the ozone 
measurement accuracy is estimated at $\pm(2 \mathrm{ppbv}+2 \%)$ for a $4 \mathrm{~s}$ response time (Thouret et al., 1998). Based on an infrared analyser, the carbon monoxide measurement accuracy is estimated at $\pm(5 \mathrm{ppbv}+5 \%)$ for a $30 \mathrm{~s}$ response time (Nedelec et al., 2003). A special airborne humidity sensing device is used for measuring relative humidity and temperature of the atmosphere (Helten et al., 1998). Measurements of total odd nitrogen are described in Volz-Thomas et al. (2005) and in Pätz et al. (2006). Measurements for more than 26000 long-haul flights are recorded in the MOZAIC data base (http://mozaic.aero.obs-mip.fr/web/) that is free-access for scientific use.

The summer period from 16 July to 31 August 2003 is analysed with respect to the MOZAIC climatology based on an 11-year dataset (1994-2004). During the episode of the heat wave (defined further down from 2 to 14 August 2003), deviations from the climatology will be referred as anomalies. We have chosen the MOZAIC data over Frankfurt airport because of its central location within the 2003 heat wave pattern and the steadily frequency of MOZAIC traffic ( $>2$ vertical profiles per day). The interest of MOZAIC data over Paris is reduced because of a technical problem on the instrumentation. Vienna, the third European MOZAIC airport, was situated on the eastern edge of the anomalous anticyclonic conditions. Accordingly, MOZAIC data over Vienna confirm the eastern drift of anomalies observed in Frankfurt at the end of the episode (not shown).

The 1994-2004 MOZAIC climatology in July-August is based on 1600 profiles of temperature, wind speed, relative humidity and ozone. Over the period 2001-2004, about 550 profiles in July-August have $\mathrm{CO}$ measurements available to establish a climatology. The $\mathrm{NO}_{\mathrm{y}}$ dataset is much more reduced with 35 profiles available for the August climatology based on 2002-2003 measurements, 6 of which being in the heat wave period. During summer in Frankfurt, the sunup is at about 04:00:00 UTC and the sunset is at about 19:00:00 UTC, so that at 09:00:00 UTC the planetary boundary layer development has already begun (local time is UTC plus $2 \mathrm{~h}$ ). In order to take account of the diurnal cycle of trace gases in the planetary boundary layer (PBL), the MOZAIC climatology is derived across two periods of the day: a period representative of day-time data (09:00:00 UTC-18:00:00 UTC) and another one representative for night-time and early morning data (21:00:00 UTC09:00:00 UTC). There are very few MOZAIC data at night in Frankfurt. With this classification, we end up with 89 flights representative of night and early morning observations as well as 73 flights representative of daytime observations, from 16 July to 31 August 2003. In time series of vertical profiles presented further down, MOZAIC data are averaged across these two time periods with anomalies calculated with respect to the corresponding climatology. The ground tracks of aircraft vertical profiles are included in a disk of $400 \mathrm{~km}$ radius around Frankfurt with a highest density in the northwest and northeast sectors. Distances from airport are about
$400,300,200$ and $100 \mathrm{~km}$ at $10-12,8,6$, and $3 \mathrm{~km}$ altitude, respectively.

\subsection{FLEXPART simulations}

In order to characterize the different air masses reaching Frankfurt during the period of study, the Lagrangian model FLEXPART (version 6.2) is used in both backward and forward modes (Stohl et al., 1998, 2005). The model is driven by ECMWF analyses and forecasts allowing a dynamical forcing every $3 \mathrm{~h}$ (ECMWF, 1995). The ECMWF model version used for this study has 60 vertical levels from the surface up to $0.01 \mathrm{hPa}$ with a $1^{\circ} \times 1^{\circ}$ latitude longitude grid. Transport in FLEXPART includes the resolved winds and some parameterized subgrid motions. FLEXPART parameterizes turbulence by solving Langevin equations (Stohl and Thomson, 1999) and convection by using a buoyancy sorting principle base scheme (Emmanuel and Živković-Rothman, 1999; Seibert, 2001). PBL height calculation is made using the critical Richardson number concept.

In the backward mode for tracing the origin of air masses, sets of 20000 particles are fitted into boxes placed along the aircraft profiles with a vertical size of $250 \mathrm{~m}$ and a horizontal size of $0.5^{\circ} \times 0.5^{\circ}$. Retroplumes are initialized by releasing particles over $1 \mathrm{~h}$ time intervals. The backward mode results are used to highlight both air mass sources and air mass transport through the evolution of the retroplume geographic extension by changing atmospheric conditions.

In the forward mode, FLEXPART has been previously used for many objectives among which to show the intercontinental transport of $\mathrm{CO}$ from boreal forest fires (Damoah et al., 2004) and to compare the impact of this long-range transport to that of regional $\mathrm{CO}$ anthropogenic emissions from Europe and North America (Forster et al., 2001). Our strategy here is to strengthen the results of the backward simulations by investigating the fate of some of the continental sources of CO (i.e., Europe and North America) and of the biomass fire $\mathrm{CO}$ sources over Portugal.

The anthropogenic $\mathrm{CO}$ (AN-CO) emissions from North America and Europe are prescribed by tagging the source regions based on the EDGAR version 3.2 emission dataset valid for 2000 (EDGAR: Emission Database for Global Atmospheric Research, http://www.mnp.nl/geia/data/Carbon_ Monoxide/) (Olivier et al., 2002). We select EDGAR emission into the domain $\left[125^{\circ} \mathrm{W}-70^{\circ} \mathrm{W}, 29^{\circ} \mathrm{N}-50^{\circ} \mathrm{N}\right]$ for North America and into the domain $\left[10^{\circ} \mathrm{W}-40^{\circ} \mathrm{E}, 37^{\circ} \mathrm{N}-\right.$ $60^{\circ} \mathrm{N}$ ] for Europe. The annual emissions are scaled to a 62-day period corresponding to the simulation emission period (1 July to 31 August 2003). During this period North America and Europe emit $12.83 \mathrm{Tg}$ and $10.75 \mathrm{Tg}$ of CO, respectively. In FLEXPART simulations, a set of $20 \times 10^{6}$ particles is used to initialize anthropogenic $\mathrm{CO}$ emissions released in $1^{\circ} \times 1^{\circ}$ latitude-longitude boxes between $0 \mathrm{~m}$ and $150 \mathrm{~m}$ above ground level. Diurnal variations of anthropogenic emission are not taken into account, which leads to 
Table 1. Daily emission of $\mathrm{CO}$ from fires. Geographical limits $\left(36^{\circ} \mathrm{N}-42^{\circ} \mathrm{N}, 10^{\circ} \mathrm{W}-7^{\circ} \mathrm{W}\right)$.

\begin{aligned} & \hline Date Mass $(\mathrm{Gg}) \\ &$\hline 29 Jul 37.6 \\ & 30 Jul 41.2 \\ & 31 Jul 41.2 \\ & 1 Aug 8.0 \\ & 2 Aug 97.6 \\ & 3 Aug 562.7 \\ & 4 Aug 282.1 \\ & 5 Aug 16.6 \\ & 6 Aug 27.5 \\ & 7 Aug 41.9 \\ & 8 Aug 49.9 \\ & 9 Aug 34.0 \\ & 10 Aug 42.7 \\ & 11 Aug 47.7 \\ & 12 Aug 99.8 \\ & 13 Aug 77.4 \\ & 14 Aug 113.6 \\ & 15 Aug 6.5 \\ & Total 1628.0 \\ & \hline\end{aligned}

an overestimation of the nighttime emission and underestimation of the daytime emission. Averaging the two periods is not perfect because of the reduced vertical mixing and the slower horizontal transport during the night. Neither chemical loss nor dry deposition of $\mathrm{CO}$ is parameterized.

The Portuguese biomass burning CO (BB-CO) emissions are simulated by taking account of the fire day to day variations during 29 July to 15 August 2003 period. We have counted the daily number of forest fires detected by MODIS during the period and the total number of detected fires from 1 January to 20 August 2003 into the $\left[10^{\circ} \mathrm{W}-\right.$ $\left.7^{\circ} \mathrm{W}, 36^{\circ} \mathrm{N}-42^{\circ} \mathrm{N}\right]$ geographic area. The MODIS Webfire Mapper (http://maps.geog.umd.edu/firms/) gives information (latitude, longitude) on the spotted fires for the day selected. We selected fires with a confidence value greater than 50 in order to avoid false alarm (Giglio, 2007). The total number of detected fires (2674) is linked to the total area burnt until 20 August 2003 (355976 ha) found in (Barbosa et al., 2003). We consider that all detected fire spots burn an equal part of the total burnt area and we end up with 133.1 ha burnt by one fire spot. An emission factor for temperate forest, which corresponds to $5434 \mathrm{~kg}$ of $\mathrm{CO}$ per hectare burnt, is used (Emission Inventory Guidebook, 2006). During the simulated emission period (29 July to 15 August 2003) Portuguese biomass burning emits $1.63 \mathrm{Tg}$ of $\mathrm{CO}$. The fires are selected on a $1^{\circ} \times 1^{\circ}$ latitude-longitude grid which is also the size of the release boxes. The $20 \times 10^{6}$ particles are released uniformly between $0 \mathrm{~km}$ and $3.5 \mathrm{~km}$ above sea level. The details of location and intensity of emission are given in Table 1.
In the forward mode, a stratospheric ozone tracer can be initialized by a linear relationship with the potential vorticity (PV) and is then transported with the FLEXPART model (Stohl et al., 2000; Cooper et al., 2005). In this paper, this field is initialized in the model domain $\left(140^{\circ} \mathrm{W}-49^{\circ} \mathrm{E}\right.$, $\left.21^{\circ} \mathrm{N}-81^{\circ} \mathrm{N}\right)$ and at the model boundaries, and then advected with ECMWF winds. Again, a set of $20 \times 10^{6}$ particles is used to initialize the stratospheric ozone tracer. This FLEXPART run began on 6 July 2003, 00:00:00 UTC. Criteria used to initialize the stratospheric ozone tracer are PV larger than 2 pvu (dynamical threshold for the tropopause) and height above $3 \mathrm{~km}$. The condition on height is employed to avoid tagging a tropospheric particle that has got a high $\mathrm{PV}$ value by diabatic PV production in cloudy areas as a stratospheric-origin particle. Once a particle has gone across a boundary limit of the domain, it is removed from the simulation. Stratospheric particles are given a mass of ozone according to

$M_{\mathrm{O}_{3}}=M_{\text {air }} \times \mathrm{PV} \times C \times 48 / 29$

where $\left(C=45 \times 10^{-9} \mathrm{pvu}^{-1}\right)$ is the ratio between the ozone volume mixing ratio and $\mathrm{PV}$ in the stratosphere at this time of the year, $\left(M_{\text {air }}\right)$ is a threshold that a mass of air entering the model at a grid cell has to reach to create a trajectory particle at a random location at the boundary of the grid cell and PV is the potential vorticity value at the position of a stratospheric particle. The factor $48 / 29$ converts volume mixing ratio into mass mixing ratio. The average relationship between ozone and PV in the lowermost stratosphere over Europe in July $\left(C=45 \times 10^{-9} \mathrm{pvu}^{-1}\right)$ is derived from Roelofs and Lelieveld (2000) and Narayana Rao et al. (2003). The stratospheric ozone is treated as a passive tracer, and its distribution in the troposphere is only due to transport from the stratosphere.

\section{Meteorological situation}

Figure 1 shows the temperature measurements and the associated anomalies with respect to the two periods of the day as explained in Sect. 2 for 16 July 2003-31 August 2003, from the ground up to $10 \mathrm{~km}$ altitude. Figure $1 \mathrm{a}$ clearly exhibits a period of high surface temperatures (above $25-26^{\circ} \mathrm{C}$ ) starting on 2 August 2003 and lasting until 14 August 2003. Before and after this period, temperatures were characteristic of the summer season (around $20^{\circ} \mathrm{C}$ ). Interestingly, Fig. $1 \mathrm{~b}$ shows that the anomalies between 2 August 2003 and 14 August 2003 are in excess of $5^{\circ} \mathrm{C}$ and can extend throughout the whole troposphere. This temperature anomaly represents 2 standard deviations. Finally, it is worth noting that the temperature anomaly remained positive (above $3-4^{\circ} \mathrm{C}$ ) in the free troposphere from 21 August to 28 August 2003. Considering these anomalies, our selected period of interest can be divided in three. The summer 2003 heat wave is defined here as the period of surface temperature anomalies greater than 

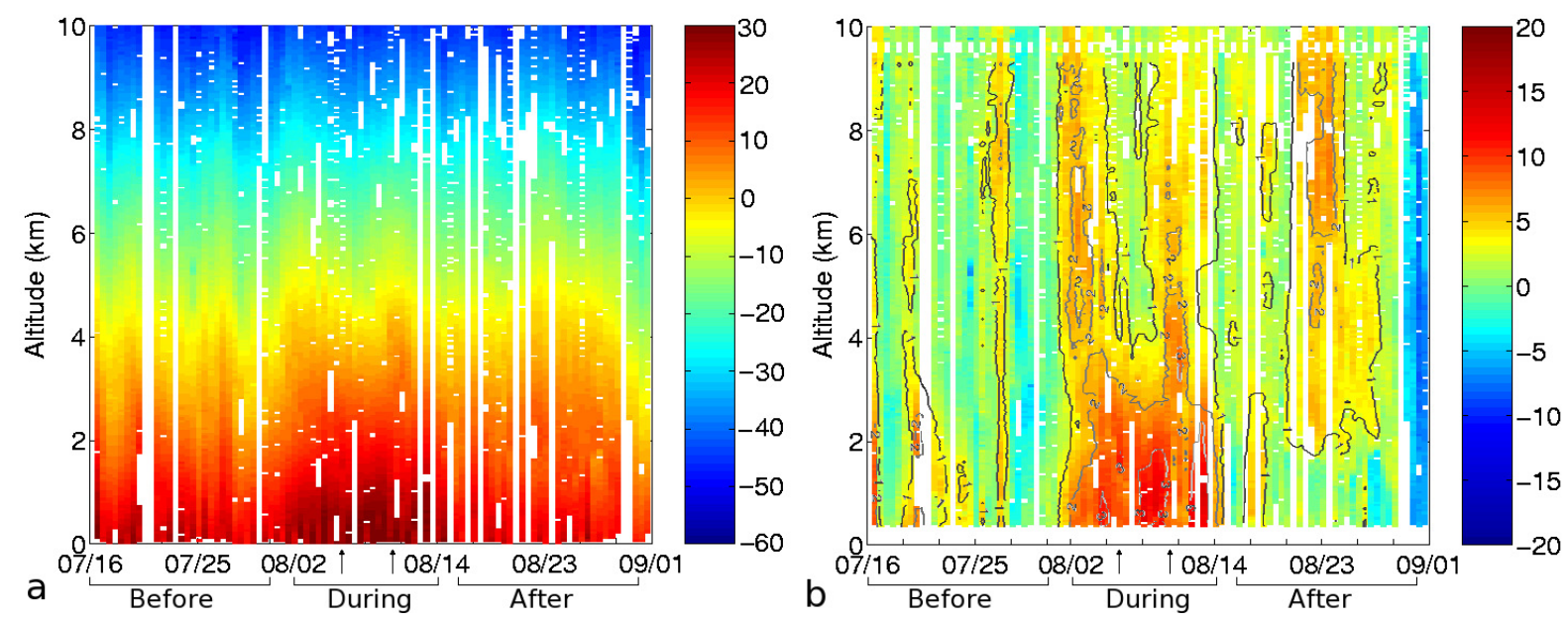

Fig. 1. Time series of MOZAIC vertical profiles of (a) temperature $\left({ }^{\circ} \mathrm{C}\right)$ and (b) temperature anomaly $\left({ }^{\circ} \mathrm{C}\right)$ from 16 July to 31 August 2003 over Frankfurt. Grey contour lines represent temperature anomalies normalised by the 11-year standard deviation of MOZAIC temperatures. Anomalies are derived versus the 11-year database. Vertical arrows indicate flights corresponding to Figs. 11 and 14.
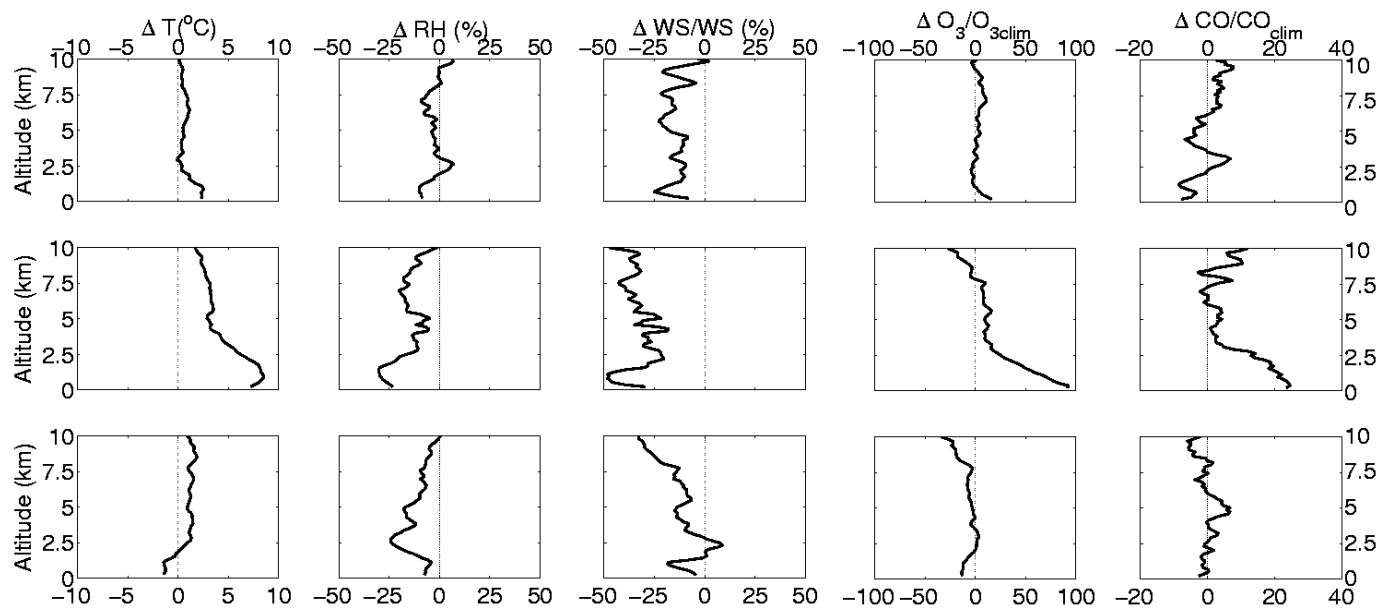

Fig. 2. Averaged vertical profiles derived from the deviations of MOZAIC observations in summer 2003 from the 1994-2004 summer climatology. Columns from left to right: temperature anomaly $\left({ }^{\circ} \mathrm{C}\right)$, relative humidity anomaly $(\%)$, normalized wind speed anomaly $(\%)$, normalized ozone anomaly (\%) and normalized CO anomaly (\%). Rows: (top) 16-31 July period, (middle) 2-14 August 2003 , (bottom) 16-31 August 2003. Anomalies are derived versus the 11-year database.

$5^{\circ} \mathrm{C}$. This way, it starts on 2 August and lasts until $14 \mathrm{Au}-$ gust. The periods 16 July to 31 July 2003 and 16 August to 31 August 2003 will be referred hereafter as before and after the heat wave, respectively.

In the planetary boundary layer (PBL), temperatures remained $10^{\circ} \mathrm{C}$ above the climatological values between $2 \mathrm{Au}$ gust and 14 August. Temperature anomaly exceeded 3 standard deviations on the 5, 8 and 11 August in the PBL. In the free troposphere, temperature anomaly remains in excess of one standard deviation for the whole heat wave except on the 6, 7 and 8 August when anomaly is close to $0^{\circ} \mathrm{C}$. During a few days around 3 and 10 August, the 2 standard deviation threshold has been exceeded.
To further investigate the meteorological situation during summer 2003, Fig. 2 illustrates MOZAIC averaged vertical profiles of anomalies for temperature, relative humidity and normalized anomaly for wind speed. Before the heat wave period, the temperature anomaly already shows weak positive values in the PBL. The wind speed anomaly reveals that winds were $10 \%$ slower than climatological conditions throughout the troposphere while relative humidity oscillated around normal values. The 13 days of the heat wave period present the strongest anomalies for the three parameters. Temperature was on average $7^{\circ} \mathrm{C}$ above normal near the ground and between $3^{\circ} \mathrm{C}$ and $4^{\circ} \mathrm{C}$ above normal from $4 \mathrm{~km}$ to $10 \mathrm{~km}$ altitude. Wind speed is lower than climatology 

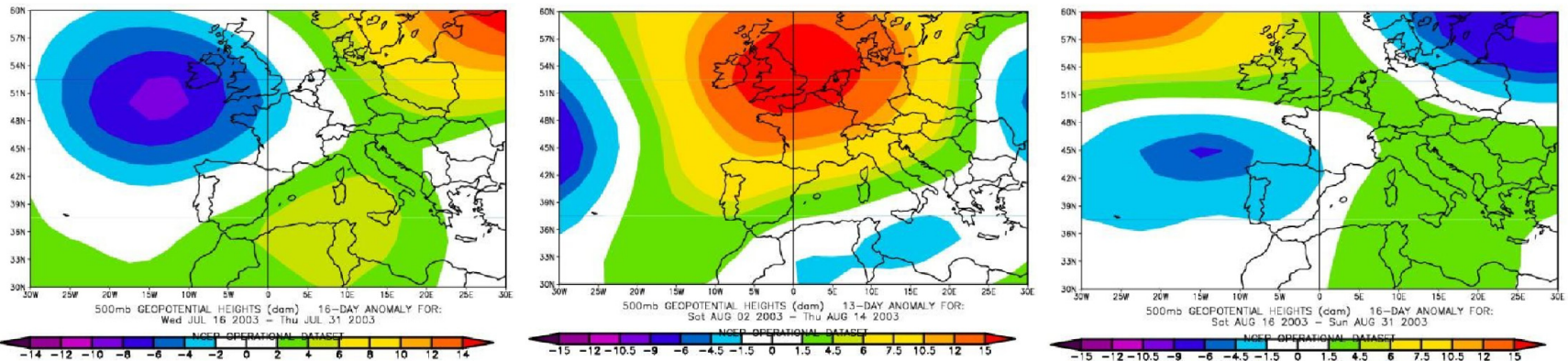

Fig. 3. Geopotential anomaly relative to $1979-1995$ at $500 \mathrm{hPa}$ from NCEP/NCAR reanalysis (left) 16-31 July 2003, (middle) 2-14 August 2003, (right) 16-31 August 2003.
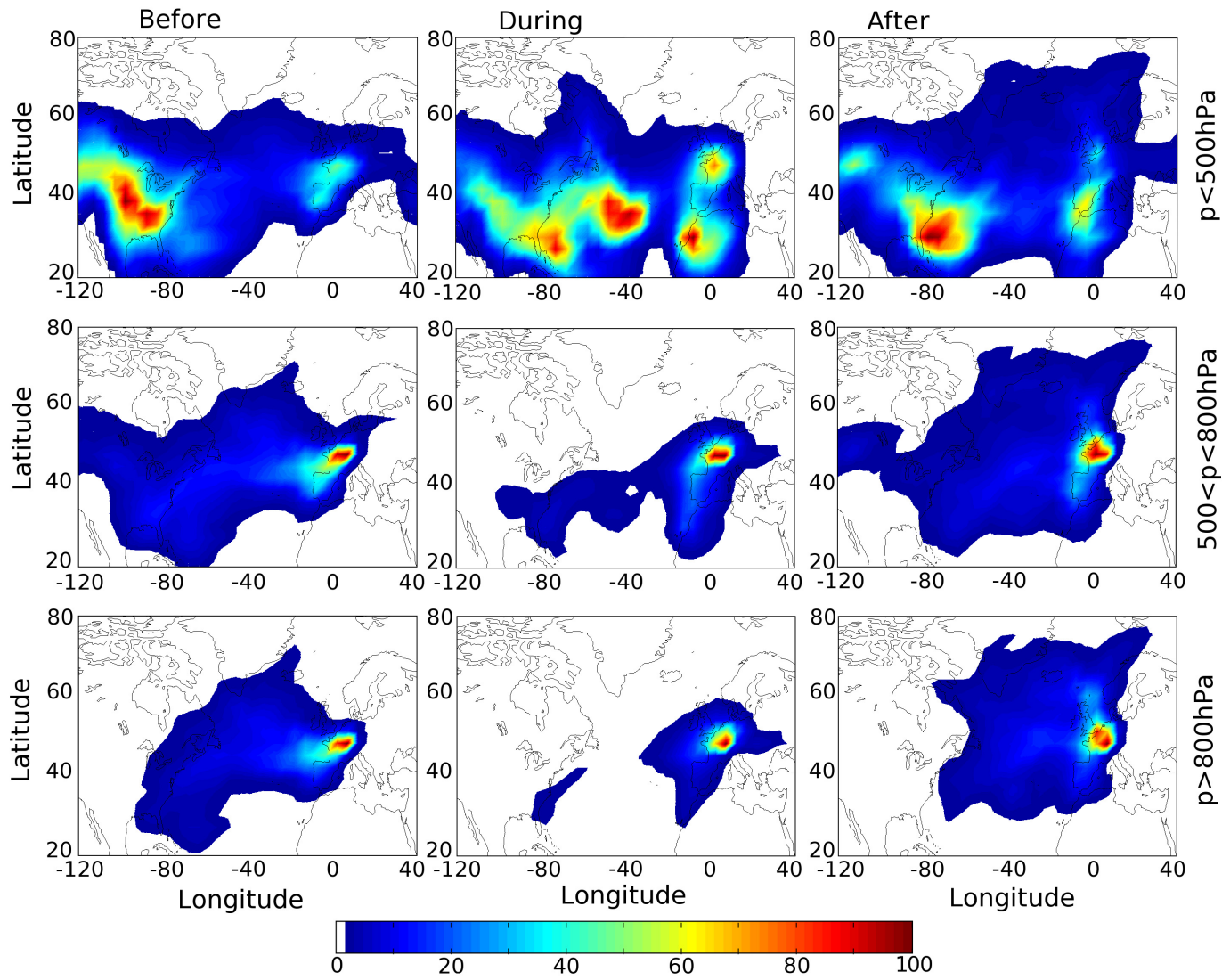

Fig. 4. Sensitivity function to emission input in the $0-3 \mathrm{~km}$ atmospheric column up to 10 days back. It is calculated as the residence times of air parcels in latitude-longitude boxes and values are given in the colour bar as percentages of the maximum. The larger percentage, the larger sensitivity air parcels have on the region with regards to emissions. Air parcels are initialized in boxes $\left(0.5^{\circ} \mathrm{C}\right.$ latitude-longitude, $250 \mathrm{~m}$ thickness) along the MOZAIC vertical profiles for 16 to 31 July 2003 (left), 2 to 14 August (center) and 16 to 31 August (right) within a 1-hour time interval. Particles are released from boxes with pressure lower than $500 \mathrm{hPa}$ (top), in the 500-800 hPa range (middle) and larger than $800 \mathrm{hPa}$ (bottom).

by $30 \%$ throughout the troposphere and relative humidity presents two deep minima, one at $1 \mathrm{~km}$ altitude and another one at around $7 \mathrm{~km}$. These anomalous features, i.e. high temperatures, low wind speeds leading to large residence times, and clear sky make environmental conditions very favourable for ozone formation. After the heat wave period, tempera- tures decrease rapidly towards climatological values. Relative humidity remained lower than usual in the free troposphere and wind speed in the upper troposphere.

The latter local observations are put into the wider context of the synoptic situation described by NCEP reanalyses (Kalnay et al., 1996) and FLEXPART simulations in 
backward mode. Figure 3 presents the geopotential anomalies at $500 \mathrm{hPa}$ from the NCEP reanalysis for the three periods defined as before. Anomalies are calculated from a 16-year climatology (1979-1995) based on a 5-day running mean of the annual cycle. In July, a mid-tropospheric trough digs in over Western Europe whereas Southern and Eastern Europe are under anticyclonic conditions. Western Europe is thus influenced by a south-westerly flow coming from the Central Atlantic. During the heat wave, a strong positive geopotential anomaly centred above England has settled over Europe. After the heat wave, the positive geopotential anomaly over Europe has disappeared.

Figure 4 illustrates the geographical coverage of the particle residence times for the period of interest in the $0-3 \mathrm{~km}$ altitude layer as simulated by FLEXPART initialized on every MOZAIC profile in Frankfurt. Different origins of these retroplumes show up depending on their arrival altitude and periods of time on MOZAIC profiles. Before and after the heat wave and for arrival altitudes in the middle and upper troposphere $(p<500 \mathrm{hPa})$, air masses are strongly influenced by the long-range transport across the Atlantic. Low pressure systems over the Eastern Atlantic favour strong westerly winds and efficient transport (Fig. 3). For arrival altitudes in the mid-troposphere $(500<p<800 \mathrm{hPa})$, retro-plumes have similar behaviour with again the presence of trans-Atlantic transport. At the lowest levels ( $p>800 \mathrm{hPa}$ ) some differences appear between the two latter periods with the presence after the heat wave of a northward extension (Iceland, Scandinavia) of the retro-plume. During the heat wave and for the upper troposphere, the retro-plume picture is more patchy with different possible origins of the air masses from the Eastern US, from the middle Atlantic (centre of the Azores high), from North-western Africa and Europe. For arrival altitudes in the lower troposphere, Fig. 4 highlights the weakness of winds by a less extended retro-plume and the southern origin of the air mass. Due to the persistence of a trough over the Atlantic $\left(20^{\circ} \mathrm{W}\right)$ together with a ridge over Spain as described by García et al. (2002), there is a predominance of a southerly flow which brought air from Portugal and the Sahara to Europe.

As previously mentioned by Hodzic et al. (2006) and Solberg et al. (2008), the period of the heat wave is itself marked by changing atmospheric conditions. Indeed, Fig. $1 \mathrm{~b}$ shows the passage of a colder air mass above $3 \mathrm{~km}$ altitude during the core of the heat wave. A weak extratropical low which moved around the anticyclone centre is responsible for this air mass change. It corresponds to a drop of the top of the PBL, from $2000 \mathrm{~m}$ altitude to $1200 \mathrm{~m}$ altitude (Fig. 5). The low appeared at the end of July over the Atlantic Moroccan coast and slowly reached Portugal on the 2 August 2003, then the South of United Kingdom on the 5 August 2003. Then, it took an easterly track above Belgium and the Netherlands, and arrived in Germany two days later. Given this sudden change of air mass properties, we define 3 sub-periods during the heat wave period (i.e. 2-5 August 2003, 6-8 August

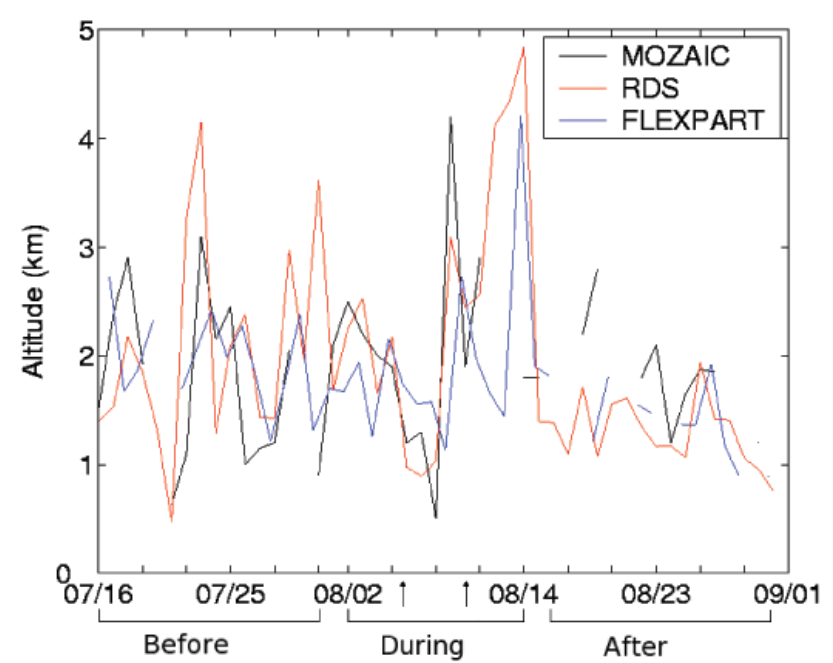

Fig. 5. Time series of planetary boundary layer height $(\mathrm{km})$ as derived from MOZAIC profiles over Frankfurt (black), and radiosoundings at Idar-Oberstein, Stuttgart and Meiningen (red), and parameterized by FLEXPART for the grid cell covering Frankfurt (blue). MOZAIC profiles are selected between 09:30:00 UTC and 19:00:00 UTC. Radiosoundings are made at 12:00:00 UTC. Hours of FLEXPART diagnoses are those of MOZAIC flights.

\section{3 and 9-14 August 2003).}

Figure 5 shows the time series of PBL heights over Frankfurt during the analyzed period. They have been derived from MOZAIC profiles and radiosounding data at 3 nearby meteorological stations as well as parameterized by FLEXPART. PBL heights are deduced from various indicators (temperature inversion, vertical gradients of relative humidity and potential temperature). Figure 6 presents three individual MOZAIC profiles, each one characteristic of one of the three sub-periods of the heatwave. The top of the PBL is at about $2.5 \mathrm{~km}$ altitude in the first sub-period, goes down to $1.1 \mathrm{~km}$ in the second sub-period, and rises to $4.5 \mathrm{~km}$ altitude during the third sub-period. The strong development of the PBL during the heat wave is associated with a feedback between soil moisture and deficit precipitation (Schär et al., 1999; Fisher et al., 2006). The soil moisture controls the energy balance between the earth surface and the atmosphere by modulating sensible and latent (evaporation) heat fluxes. A precipitation deficit like that of spring 2003 over Europe leads to dry soils, lower evapotranspiration, less latent cooling and fewer clouds, which in returns drives anomalously warm soils, larger sensible heat fluxes and a more developed PBL. This was the typical situation during the first and third subperiods of the heat wave. During the second sub-period of the heat wave, the decrease of the height of the top of the PBL is due to the ventilation of air masses by the low-pressure system coming from Morocco and Portugal. This observed drop of the top of the PBL is also captured by FLEXPART. 

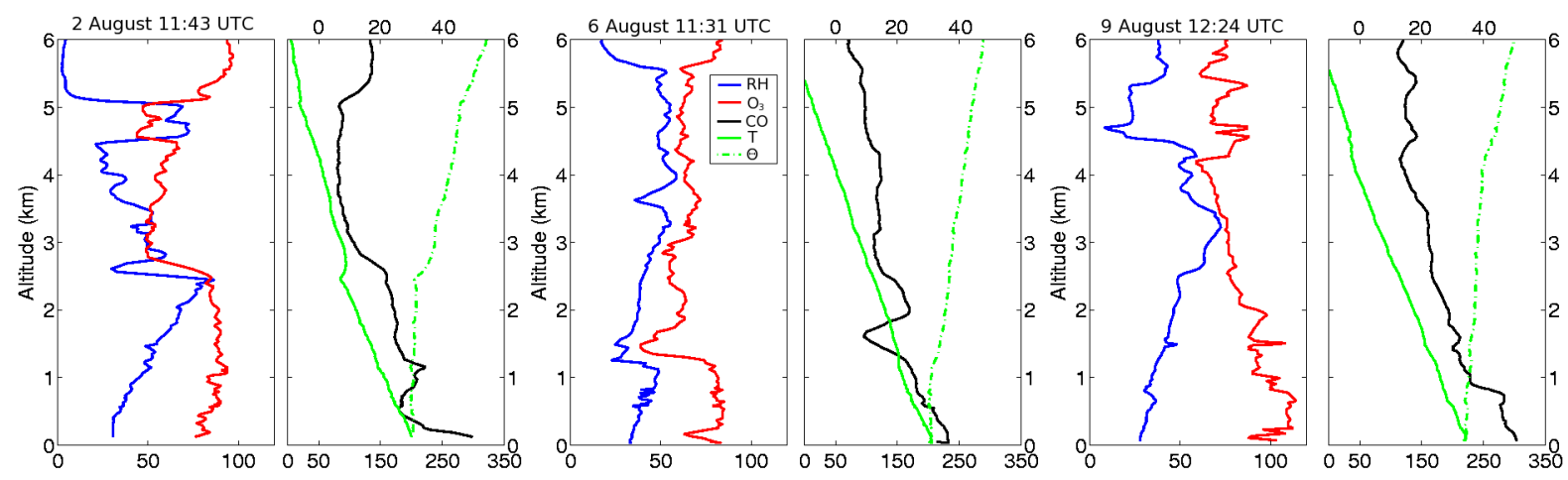

Fig. 6. Three sets of MOZAIC vertical profiles over Frankfurt, each one characteristic of one of the three sub-periods of the heat wave: 2 August 11:43:00 UTC (left), 6 August 11:31:00 UTC (center) and 9 August 12:24:00 UTC (right). The plots on the left show relative humidity $\left(\%\right.$, blue) and ozone mixing ratio (ppbv, red). The plots on the right show temperature $T\left({ }^{\circ} \mathrm{C}\right.$, green line, top axis), potential temperature $\Theta\left({ }^{\circ} \mathrm{C}\right.$, green dashed line, top axis) and carbon monoxide mixing ratio (ppbv, black, bottom axis). The top of the PBL is around $2500 \mathrm{~m}$ altitude (left), $1125 \mathrm{~m}$ (center) and $4500 \mathrm{~m}$ (right).

\section{Characteristics of ozone and $\mathrm{CO}$ vertical distributions during the heat wave}

To complete the description made with surface observations over Central Europe (Fiala et al., 2003; Vautard et al., 2005), $\mathrm{O}_{3}$ and CO MOZAIC data are now investigated. For the three periods defined earlier during the summer 2003, Fig. 2 shows the normalized anomalies for ozone and $\mathrm{CO}$ based on the climatology from all MOZAIC observations (11 years for ozone and 3 years for $\mathrm{CO}$, see Sect. 2 for more details). Before the heat wave, the ozone and $\mathrm{CO}$ mean profiles do not show any significant anomaly. During the heat wave, positive anomalies show up for the two species in the low troposphere and increase down to the surface. Near the surface, ozone is almost two times higher than normally and $\mathrm{CO}$ is more than 20\% higher. Mid-tropospheric anomalies are not significant. In the upper troposphere, anomalies of ozone and CO have opposite variations that correspond to the raising of the tropopause height compared to the climatology and probably to the occurrence of biomass burning plumes in the upper troposphere. After the heat wave, ozone and CO profiles do not present any significant anomaly throughout the troposphere except for ozone above $8 \mathrm{~km}$ altitude where the normalized anomaly remains negative as observed during the heat wave period.

In the following, we analyse measurements from 04:00:00 UTC to 08:00:00 UTC (early morning observations) during the heat wave period as well as 3 other datasets from 08:00:00 UTC to 16:00:00 UTC (mid-day observations) during the three sub-periods of the heat wave (see end of Sect. 3). Early morning profiles averaged over the heat wave period are first compared to the MOZAIC climatology (Fig. 7a, b). The feature of interest that appears on the $\mathrm{O}_{3}$ profile is the positive anomaly up to $30 \mathrm{ppbv}$ in excess of the climatology in the residual layer at about $1 \mathrm{~km}$ altitude that rapidly decreases to zero close to surface. The positive anomaly that persists into the night is indicative of a strong daytime formation of ozone in the boundary layer. The fact that there is no anomaly at the ground is a consequence of both the accumulated surface deposition during the night and the fast titration of ozone by NO emissions in the early morning near the airport (Pison and Menut, 2004). The CO burden in the residual layer is up to $40 \mathrm{ppbv}$ in excess of the climatology over the heat wave period.

In the first sub-period of the heat wave (Fig. 7d, e), $\mathrm{O}_{3}$ concentrations show a positive anomaly up to $40 \mathrm{ppbv}$ in excess of the climatology in the planetary boundary layer (PBL). The ozone anomaly fills up the PBL up to $2.5 \mathrm{~km}$ altitude. The averaged $\mathrm{CO}$ profile displays a large variability in the middle and upper troposphere compared to the climatology. The positive departures are the signatures of biomass burning plumes coming from Portugal (see Sect. 5). The positive ozone anomaly of about $10 \mathrm{ppbv}$ observed in the $5-8 \mathrm{~km}$ altitude layer is an indication that these plumes are photochemically active. The CO burden of the PBL in this time period exceeds the climatological value by up to $30 \mathrm{ppbv}$. During the passage of the weak extratropical cyclone (Fig. 7f, g), the top of the PBL drops down decreasing the depth of the ozone anomaly to only $1200 \mathrm{~m}$ though its intensity keeps the same. Biomass fire plumes with origin over Portugal may also be present in this air mass and descend down to $2.5 \mathrm{~km}$. During the last heat wave sub-period (Fig. 7h, i), the rise in height of the top of the PBL is associated with the largest vertical extensions of $\mathrm{O}_{3}$ and $\mathrm{CO}$ anomalies up to $6 \mathrm{~km}$ altitude. Elevated concentrations of the order of 80-90 ppbv are observed for ozone while the $\mathrm{CO}$ profile overpasses the climatology from $90 \mathrm{ppbv}$ at the surface to $40-50 \mathrm{ppbv}$ at $4 \mathrm{~km}$ altitude. In the upper troposphere, anomalies of ozone become negative while $\mathrm{CO}$ anomalies stay positive. It is in agreement with the raising of the tropopause height under anticyclonic conditions compared to the climatology. 

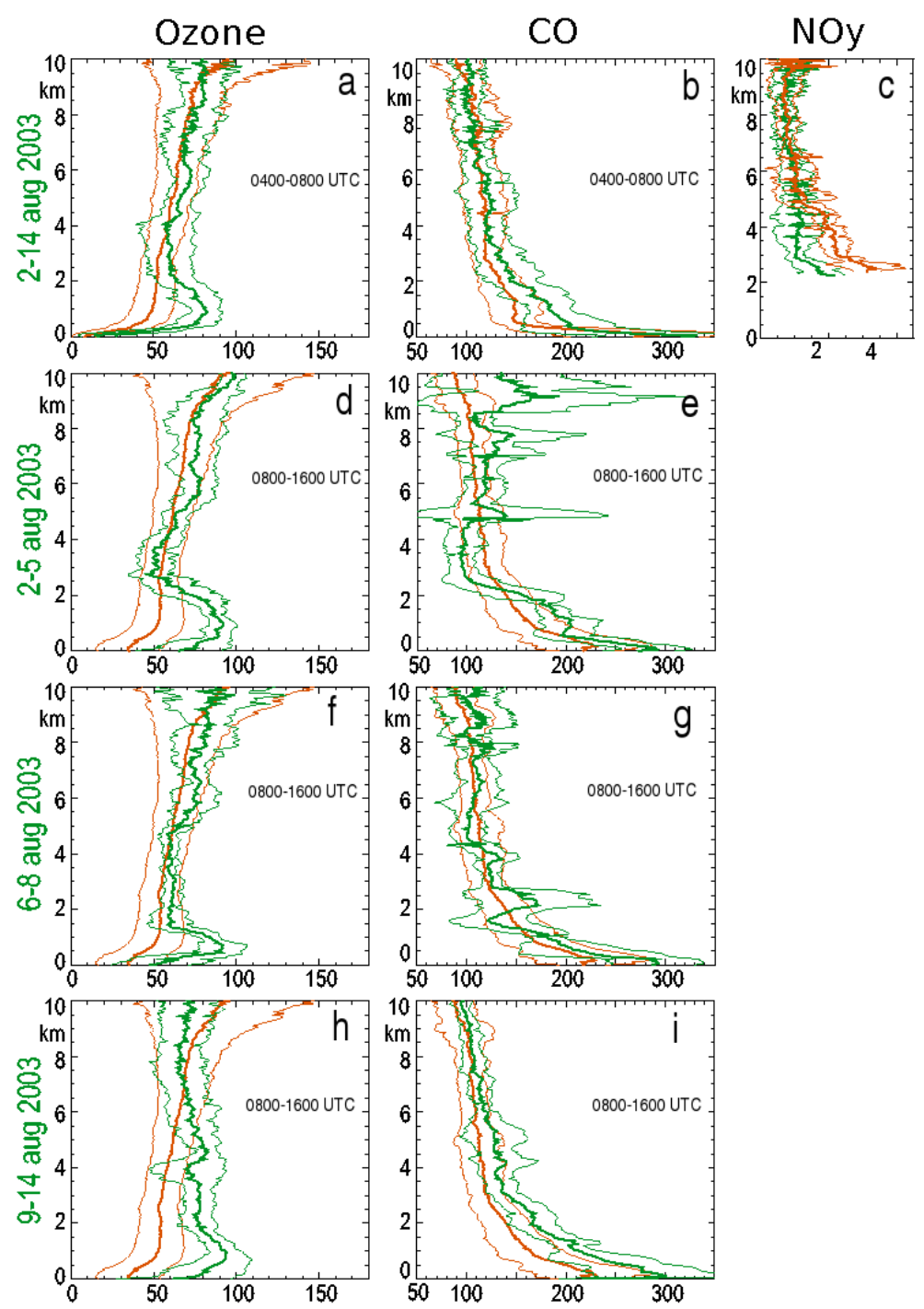

Fig. 7. Ozone (left), $\mathrm{CO}$ (middle) and $\mathrm{NO}_{\mathrm{y}}$ profiles during the period and the sub-periods of the heat wave (green) and for the climatology (orange). Dots represent the standard deviation. $\mathrm{NO}_{\mathrm{y}}$ measurements are averaged whatever the hour of the day. Units are ppbv.

Finally, Fig. 7c compares the $\mathrm{NO}_{\mathrm{y}}$ August climatological profile and the average profile for the heat wave period. Caution in the interpretation is needed here because of the few profiles available (see Sect. 2). The $\mathrm{NO}_{\mathrm{y}}$ concentrations during the heatwave are almost constant throughout the troposphere and are in fact lower than the climatological average in August. The MOZAIC NO into the PBL, because the instrument is always shut off before landing (see Volz-Thomas et al., 2005). The variance of $\mathrm{NO}_{\mathrm{y}}$ during the heat wave is similar to that of the climatology over Frankfurt in August. As the number of $\mathrm{NO}_{\mathrm{y}}$ profiles is very limited during the heat wave, it is difficult to conclude on possible reasons, such as losses due to uptake on aerosol followed by washout or deposition, for this unexpected finding.
Figure 8 illustrates the time series of ozone and $\mathrm{CO}$ anomalies in vertical profiles during the heat wave period. Data are vertically averaged over 50-m layers and over the two daytime periods before to be compared to the corresponding climatologies. As expected, results show again elevated ozone overpassing the climatological value by more than $40 \mathrm{ppbv}$ over the heat wave period, as well as the change in the vertical structure of the ozone anomaly due to the passage of the extratropical low with the anomaly trapped below $2 \mathrm{~km}$ altitude in the second sub-period. The structure of the $\mathrm{CO}$ anomalies in the time series bear some resemblance with the ozone one, with additional large midand upper-tropospheric anomalies (up to $150 \mathrm{ppbv}$ ) associated with plumes of biomass fires (see Sect. 5). 

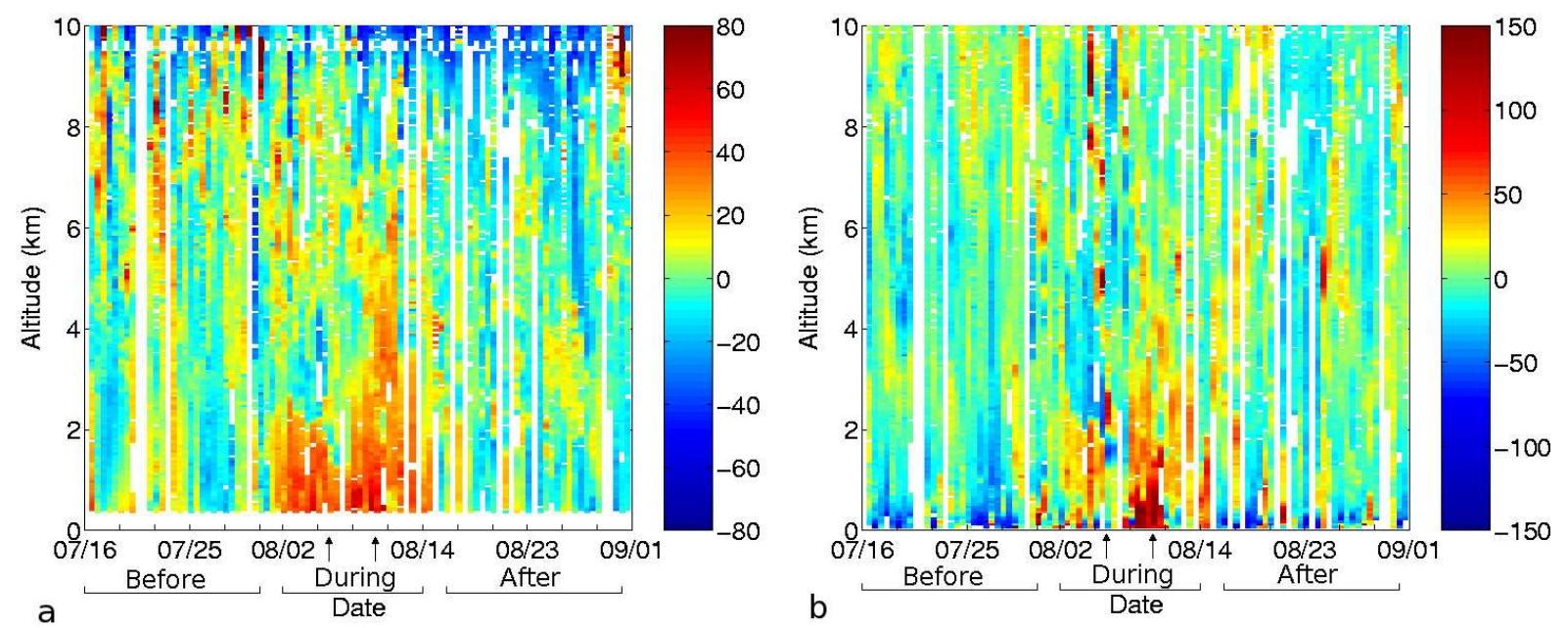

Fig. 8. Time series of MOZAIC vertical profiles of (a) ozone and (b) CO anomalies (ppbv) from 16 July to 31 August 2003 over Frankfurt. Anomalies are derived versus the 11-year database.

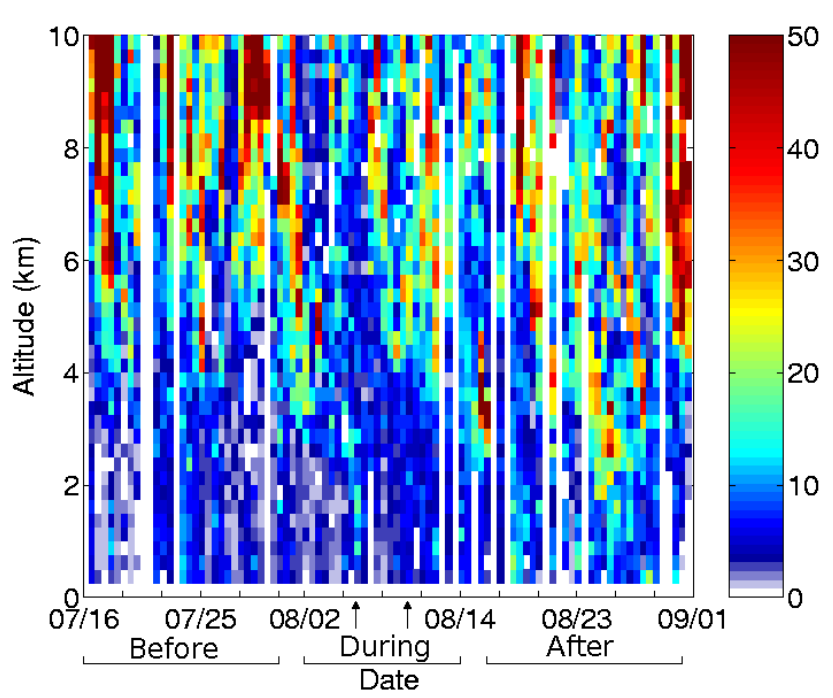

Fig. 9. Time series of vertical profiles of the FLEXPART stratospheric-origin ozone tracer over Frankfurt. Values are given as percentages of the MOZAIC ozone observations at Frankfurt (\%).

\section{Origins of ozone and $\mathrm{CO}$ maxima during the heat wave}

In this section, we investigate the origins of the observed maxima of $\mathrm{O}_{3}$ and $\mathrm{CO}$ using the FLEXPART model. The model is used in the forward mode to simulate the dispersion and transport of tagged sources which are the stratospheric ozone, $\mathrm{CO}$ from Portuguese biomass burning fires (BB-CO), and $\mathrm{CO}$ from anthropogenic emissions (AN-CO). In addition, the model is used in the backward mode to investigate the origins of $\mathrm{CO}$ anomalies observed along the MOZAIC profiles. Information on the simulations is in Sect. 2.2.

\subsection{Stratospheric-origin ozone intrusions and anticyclonic} subsidence

Figure 9 shows the modelled contribution of stratosphericorigin ozone to the MOZAIC observations. The stratospheric contribution below $4 \mathrm{~km}$ is insignificant (less than 10\%) during the heat wave. Between 4 and $6 \mathrm{~km}$ altitude and during the last sub-period of the heat wave, patchy stratospheric contributions from $15 \%$ up to $30 \%$ are modelled. It indicates that the ozone anomaly that extends up to $6 \mathrm{~km}$ during this sub-period (Fig. 8a) may be partly due to stratospheric intrusions. Above $6 \mathrm{~km}$ altitude, many potential cases of stratospheric intrusions show up but they are outside the scope of the present study.

We further investigate the effect of the subsidence anomaly on ozone profiles. With the aid of particle backward trajectories, the average subsidence of the mid-tropospheric geopotential anomaly in the area can be assessed to about $400 \mathrm{~m} /$ day with extreme values up to $1000 \mathrm{~m} /$ day for very few particles. It is therefore plausible that this downward transport contributed to the positive ozone anomalies observed in the mid-troposphere. In addition, this midtropospheric subsidence combined with the rising of the top of the PBL during the third sub-period might have enabled the capture of fire plumes within the PBL.

\subsection{Anthropogenic $\mathrm{CO}$ emission}

A CO budget analysis on an annual mean has been made for Europe from a simulation of a global chemistry transport model (Pfister et al., 2004). Model simulations have been performed with the $\mathrm{CO}$ being tagged according to the emission type and the source region, with both a priori emissions and an optimized set of CO surface emissions derived from the inversion of $\mathrm{CO}$ retrievals of the Measurements of 

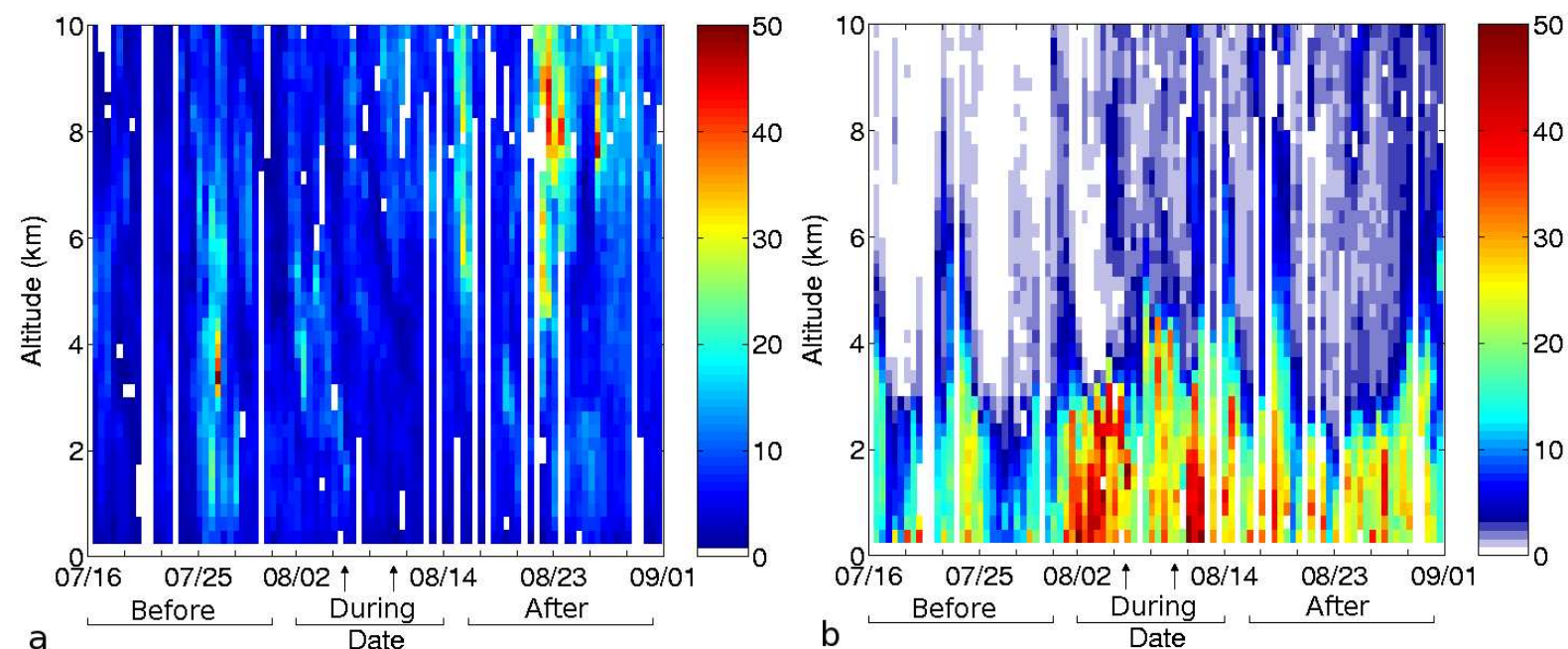

Fig. 10. Time series of vertical profiles of (a) North-American and (b) European FLEXPART anthropogenic CO tracer over Frankfurt. Values are given as percentages of the MOZAIC CO observations at Frankfurt (\%).

Pollution in the Troposphere (MOPITT) remote sensing instrument. They have been used to diagnose the contributions of different processes and regions to the $\mathrm{CO}$ burden over $\mathrm{Eu}-$ rope. Results show the predominant impact near the surface of the European source regions (37\% of the total CO concentrations), compared to North America and Asia source regions (about $8 \%$ for each one), the main part of the rest (45\%) being the contribution of photochemical CO. With increasing altitude, the contribution of the European source regions weakens $(8 \%$ at $500 \mathrm{hPa})$, while the contributions of North American and Asian source regions gain in importance, reaching maximum contributions of $15 \%$ each at $500 \mathrm{hPa}$, the main part of the rest $(55 \%)$ being the contribution of photochemical CO. Note that Pfister et al. (2004) include biomass burning and biogenic emissions in source regions.

With the more focused objective to compare contributions of AN-CO sources from North America and Europe and modelled BB-CO from Portuguese forest fires to observed $\mathrm{CO}$, our approach includes the following limitations. Potential differences of EDGAR-based anthropogenic emissions between 2000 and 2003 are neglected. The annual emissions are scaled to emissions during the period of interest. There is no anthropogenic emission of $\mathrm{CO}$ elsewhere than over $\mathrm{Eu}-$ rope and North America. There is no dry deposition of CO. We consider that the previous limitations may have little implication in our approach. More worrying is the influence of photochemistry on $\mathrm{CO}$ that is lacking, which prevents to assess the background of $\mathrm{CO}$ in the troposphere. This limitation includes the photochemical generation of $\mathrm{CO}$ by gas phase oxidation of VOCs. This contribution is about 10$15 \%$ near the surface (Pfister et al., 2004), ranging from CO mixing ratios of $20 \mathrm{ppbv}$ under biogenic influence to $45 \mathrm{ppbv}$ under anthropogenic influence (Griffin et al., 2007). It could be particularly important in 2003 because of the extra evaporation of anthropogenic VOCs (Vautard et al., 2005).

Contributions of AN-CO sources from North America and Europe to observed $\mathrm{CO}$ are now investigated. The strong anticyclonic conditions that prevail over Europe during the heat wave shift the westerly flow to the North, so that one must expect a lowering of the contribution of North American pollution during this period. Indeed, results of our simulation (Fig. 10a) show an overall weak contribution (i.e. less than $10 \%$ ) of AN-CO sources from North America. The highest North American contribution (about 15-20\%) is found around $4 \mathrm{~km}$ altitude at the beginning of the heat wave period. The high modelled contribution of North American AN-CO for the mid- to upper-troposphere after the heat wave is out of the scope of this analysis.

European AN-CO emissions (Fig. 10b) lead to relatively strong contributions during the heat wave period. A maximum (minimum) in intensity of about $40 \%(20 \%)$ is produced over the first (second) sub-period, while during the third sub-period the contribution re-increases to about 30$40 \%$ and vertically extends up to $4 \mathrm{~km}$ altitude. This time evolution is coherent with the evolving meteorological conditions, in particular the decreasing contribution during the second sub-period at the expense of the BB-CO contribution as shown further down. Furthermore, the mean intensity of this contribution (about $30 \%$ below $2 \mathrm{~km}$ to $3 \mathrm{~km}$ altitude) for the whole heat wave is quite comparable to the previous modelling study (Pfister et al., 2004) despite the lack of biomass burning and biogenic emissions in this simulation. This may be the consequence of the stagnation of lower tropospheric air masses over Europe during this episode. The correlation between European AN-CO and observed CO values have been calculated. Given the limitations of our approach, the 0.5 to 0.7 correlation coefficients in the surface 


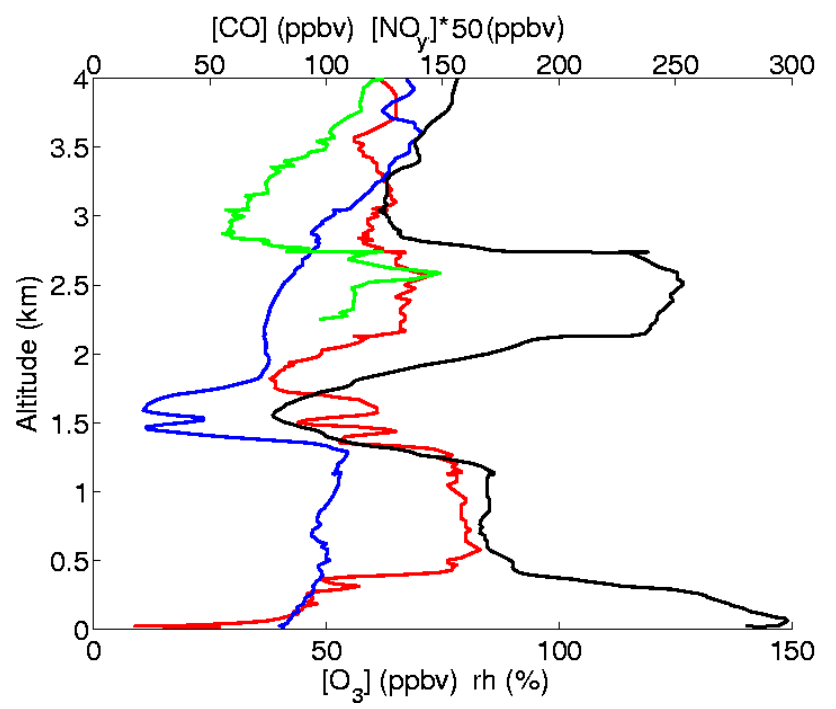

Fig. 11. MOZAIC profile at Frankfurt on 6 August 2003 08:40:00 UTC. Top axis: $\mathrm{CO}$ (black) mixing ratio and $50 \times \mathrm{NO}_{\mathrm{y}}$ (green) mixing ratio (ppbv); Bottom axis: ozone mixing ratio (ppbv, red) and relative humidity (\%, blue).

layer during the heat wave period are indicative of a significant contribution of European sources to the measured $\mathrm{CO}$ mixing ratios, with a possible impact on ozone production.

\subsection{Biomass burning $\mathrm{CO}$ emissions}

Major source regions of biomass burning in Southern Europe as well as of Saharan dust and the subsequent transport of the polluted air masses have been pointed out in previous work based on surface ozone measurements, e.g. (Solberg et al., 2008), and surface aerosol characterization, e.g. (Immler et al., 2005; Pace et al., 2005). These papers suggest a potential impact of Portuguese forest fires over northern Europe. The time series of MOZAIC vertical profiles over Frankfurt and a FLEXPART simulation of BB-CO Portuguese emissions are further investigated in this section to compare the potential impact of the forest fire emissions relatively to the anthropogenic European emissions.

From Fig. 8b, several occurrences of strong $\mathrm{CO}$ anomalies are easily detected in the troposphere between 3 and $6 \mathrm{Au}-$ gust 2003. As an example, we choose the CO anomaly of about $100 \mathrm{ppbv}$ occuring between 2 and $3 \mathrm{~km}$ altitude on 6 August 2003 during the episode of the change of air mass, i.e. the second sub-period of the heat wave. The corresponding MOZAIC profile (Fig. 11) shows a CO layer (250 ppbv) between $2 \mathrm{~km}$ and $3 \mathrm{~km}$ altitude, well correlated with relative maxima of $\mathrm{NO}_{\mathrm{y}}(3 \mathrm{ppbv})$ and ozone $(70 \mathrm{ppbv})$. These values are very close to the ones measured during the third Lagrangian flight across an Alaskan forest fire plume aged of about a week over the North Atlantic and for which observed ozone levels increased by 17 ppbv over 5 days (Real et al., 2007). In order to assess the origin of the CO layer, the FLEXPART Lagrangian model is used.

In the forward mode the transport of BB-CO emissions (Fig. 12a) shows the plume of biomass burning being embedded in the dynamics of the weak extratropical low, bypassing the western and northern edge of the anticyclone from Portugal to United Kingdom and then moving towards the southeast over Frankfurt. The MOZAIC aircraft at $2.5 \mathrm{~km}$ altitude is located inside the fire plume nearby a local maximum of BB-CO of about 100 ppbv. In the backward mode, Lagrangian trajectories are initialized where the $\mathrm{CO}$ mixing ratios exceed $150 \mathrm{ppbv}$ between $1.5 \mathrm{~km}$ and $3 \mathrm{~km}$ altitude above Frankfurt. Figure $12 \mathrm{~b}$ shows the emission sensitivity distribution up to 3 days back in the $0-3 \mathrm{~km}$ atmospheric column for trajectory particles arriving along the chosen piece of the MOZAIC flight path. Largest values are observed over western Spain and Portugal, indicating that fire emissions introduced into the atmospheric column above the region of Portuguese fires would have a strong influence on the measured concentrations.

From the observed levels of pollutants in the plume and in layers below and above, it is possible that $\mathrm{O}_{3}$ has increased up to $20 \mathrm{ppbv}$ during the transport. However, such an interpretation is problematic as several photochemical processes may interact during the transport of the biomass burning plume. $\mathrm{O}_{3}$ changes are very dependent on temperature changes during the transport. Trajectory particles arriving at $2.5 \mathrm{~km}$ altitude on the MOZAIC profile were transported below $5 \mathrm{~km}$, with $61.5 \%$ of it in the $0-3 \mathrm{~km}$ altitude layer, and $38.5 \%$ in the $3-5 \mathrm{~km}$ altitude layer. Hence, with most of the particles being transported at low altitudes, the chemical activity of this plume might involve the PAN decomposition at relatively high temperatures, including during the arrival phase over Frankfurt in the second sub-period of the heat wave for which FLEXPART indicates a descent (adiabatic heating) of the plume. In contrast, there was also considerable transport of fire smoke and Saharan dust in this period (Hodzic et al., 2006). Real et al. (2007) show that the influence of high aerosol loading on photolysis rates in a forest fire plume is a slowing down of the photochemistry (formation and destruction). Mixing with background concentrations is another process participating to the observed levels of pollutants in the plume. To sum up, this profile highlights that regional transport of $\mathrm{CO}$ from forest fires over Portugal might have affected the European PBL, although there is still a considerable gap of about $1 \mathrm{~km}$ depth to fill in between the biomass burning plume and the polluted residual layer at this time period of the heat wave over Frankfurt.

\subsection{Discussion on the existence of fire-produced CO in the} boundary layer

Here, after discussing the limitations in our approach, we further assess the potential of Portuguese fire plumes to pollute the PBL over Frankfurt. With regard to biomass fire 

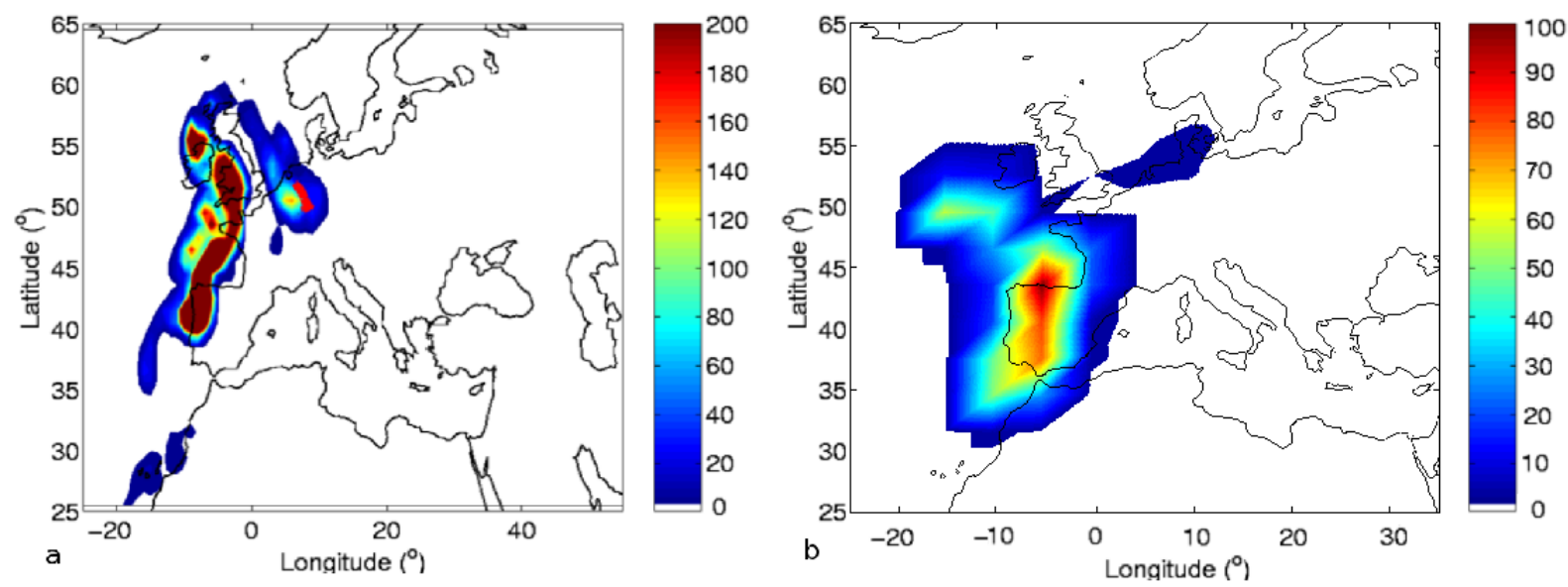

Fig. 12. (a) FLEXPART CO fire plume (ppbv) horizontal section at $2.5 \mathrm{~km}$ altitude on 6 August 2003 at the time of the MOZAIC profile shown on Fig. 11. The MOZAIC aircraft path around $2.5 \mathrm{~km}$ altitude is superposed in red. (b) Emission sensitivity distribution in the $0-3 \mathrm{~km}$ column for trajectory particles arriving along the MOZAIC profile displayed on Fig. 11. Particles were released only where the measured $\mathrm{CO}$ exceeded 150 ppbv. Residence times were calculated from arrival until 3 days back and values are given as percentage of the maximum.

emissions, the vegetation type is closer to the temperate forest (eucalytus and maritime pines) than to the Mediterranean scrubland in the central part of Portugal where fires were active. Accordingly, the simulation presented here, with a temperate forest emission factor of $5434 \mathrm{kgCO} / \mathrm{ha}$, better matches with MOZAIC observations than another simulation (not shown) having the Mediterranean scrubland emission factor $(1456 \mathrm{kgCO} / \mathrm{ha})$. This second simulation severely underestimates observed $\mathrm{CO}$ levels elsewhere than over Portugal. With regard to injection heights, Immler et al. (2005) reported with lidar observations in Linderberg (Germany) layers of aerosol coming from Portugal throughout the troposphere in August 2003. MOZAIC observations show that $\mathrm{CO}$ plumes extend up to $10 \mathrm{~km}$ altitude. Fromm et al. (2000) have suggested that extreme convection triggered by forest fires may be able to inject aerosol into the stratosphere at high latitudes. In the present case, when progressing from Portugal to United Kingdom, the weak extratropical low was associated with deep convective cells and lightning activity as it can be seen with satellite images and with the European lightning network (not shown). Convection over Portugal or over the Bay of Biscay may have uplifted aerosols and $\mathrm{CO}$ emissions. In order to test the influence of injection height of biomass fire plumes, FLEXPART simulations have been made with $0-3.5 \mathrm{~km}$ or $0-6 \mathrm{~km}$ injection heights. Our sensitivity study (not shown) indicates that the FLEXPART simulation presented here with lower injection heights better displays BB-CO plumes crossed by MOZAIC aircraft than the one with higher injection heights.

Contributions of the prescribed Portuguese fire emissions to the $\mathrm{CO}$ measurements during the period of study are now discussed (Fig. 13). The first simulated BB-CO plumes arrive over Frankfurt during the second sub-period (6 August to 8 August), when northern Europe is under the influence of the extratropical low. These plumes arrive with a delay of about one day compared to the MOZAIC time series and have BB-CO mixing ratios in the upper- (lower-) troposphere too weak (large) compared to measurements. Then, contributions from fire emissions are consistently found until 15 August 2003, and the last plume is found around 18 August 2003 after the end of the heat wave period. During the second sub-period of the heat wave, biomass burning can contribute to almost $80 \%$ of some of the observed $\mathrm{CO}$ mixing ratios at around $3 \mathrm{~km}$. Both the too high and too low contributions in the lower troposphere and upper troposphere, respectively, might be explained by the absence of ECMWF simulated convection along trajectories or by deficiencies in the FLEXPART convective scheme. During the third subperiod, the contribution of fire emissions decreases to values below $40 \%$, with maxima in the $1 \mathrm{~km}$ to $4 \mathrm{~km}$ altitude region.

Table 2 shows the average bias between MOZAIC observations and the sum of $\mathrm{CO}$ Flexpart simulations during the summer 2003 (16 July to 31 August 2003). Average bias is $105 \mathrm{ppbv}$ within the PBL and $95 \mathrm{ppbv}$ in the free troposphere. A large component of this bias comes from the $\mathrm{CO}$ background value that is lacking in our FLEXPART simulations. In a similar study of boreal forest fire emissions (Canada and European parts of Russia), Forster et al. (2001) estimated the CO background to about 97 ppbv. Subtracting about $90 \mathrm{ppbv}$ in our case, in order to account for the $\mathrm{CO}$ background, lowers the bias to $15 \mathrm{ppbv}$ within the PBL and to $5 \mathrm{ppbv}$ in the free troposphere. With regards to the period of smoke plumes over Frankfurt, this corrected bias is close to zero during the third sub-period within the PBL. In the free troposphere, the corrected bias varies from $-16 \mathrm{ppbv}$ (second sub-period) to $6 \mathrm{ppbv}$ (third sub-period). This indicates that the order of magnitude of $\mathrm{CO}$ associated with biomass burning is correctly estimated. The general concordance in 
Table 2. CO mixing ratio (in ppbv) from MOZAIC and FLEXPART simulations. Last line presents the bias between CO MOZAIC measurements and the sum of FLEXPART simulated CO (AN-CO and BB-CO).

\begin{tabular}{llllllllllll}
\hline CO (ppbv) & \multicolumn{3}{c}{ Before } & \multicolumn{4}{c}{ During } & \multicolumn{2}{c}{ After } \\
\hline & \multicolumn{1}{c}{ 2-5 August } & \multicolumn{3}{c}{ 6-8 August } & 9-14 August \\
Altitude (km) & $0.25-2$ & $2-8$ & $0.25-3$ & $3-8$ & $0.25-1.25$ & $1.25-8$ & $0.25-3$ & $3-8$ & $0.25-2$ & $2-8$ \\
MOZAIC observation & 149 & 116 & 162 & 114 & 218 & 126 & 181 & 123 & 156 & 117 \\
America AN-CO & 8 & 7 & 10 & 7 & 8 & 7 & 6 & 8 & 9 & 10 \\
Europe AN-CO & 23 & 5 & 50 & 4 & 52 & 15 & 50 & 10 & 37 & 8 \\
BB-CO & $\mathrm{x}$ & $\mathrm{x}$ & $\mathrm{x}$ & $\mathrm{x}$ & 51 & 30 & 35 & 9 & $\mathrm{x}$ & $\mathrm{x}$ \\
Bias & 118 & 104 & 102 & 103 & 107 & 74 & 90 & 96 & 110 & 99 \\
\hline
\end{tabular}

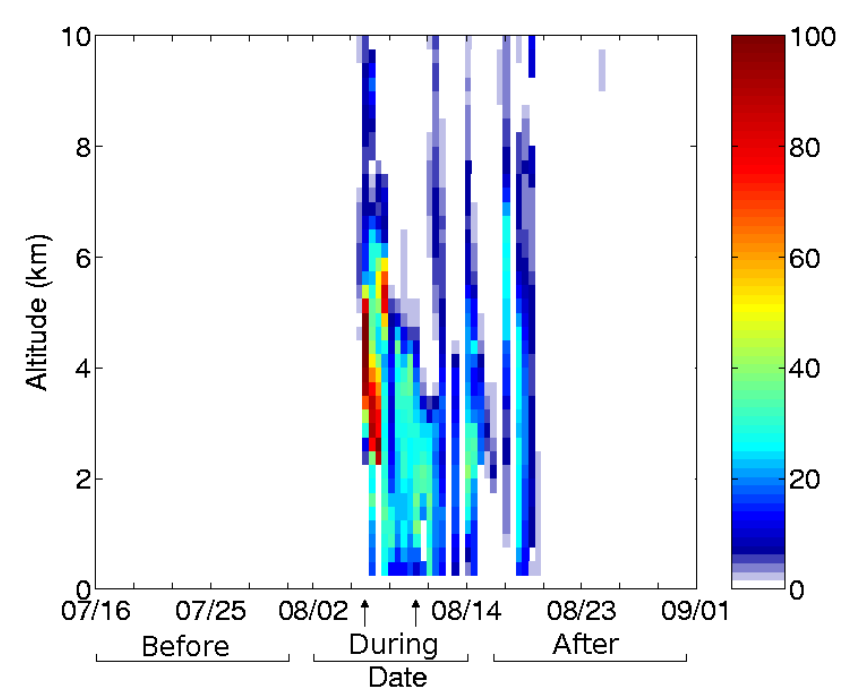

Fig. 13. Time series over Frankfurt of vertical profiles of Portuguese biomass burning $\mathrm{CO}$ transported with FLEXPART. Values are given as percentages of the MOZAIC CO observations (\%).

time between the contribution of BB-CO (Fig. 13) and the largest MOZAIC CO anomaly (Fig. 8b) confirms the impact of Portuguese forest fires on the pollution level over Frankfurt.

During the third sub-period of the heat wave when the top of the PBL has risen up, we very tentatively look at signatures in MOZAIC profiles that could be representative of fire plumes being mixed inside the PBL. Figure 14 shows two MOZAIC vertical profiles sampled on 10 August 2003, 04:46:00 UTC and 08:34:00 UTC. According to Fig. 5, the top of the PBL has risen after the weak surface low has left central Europe, and it is at about $4.5 \mathrm{~km}$ height on $9 \mathrm{Au}-$ gust 12:00:00 UTC and at about $2.5 \mathrm{~km}$ height on 10 August 12:00:00 UTC. In the first profile (Fig. 14a), the layer just below $3 \mathrm{~km}$ altitude contains relative maxima of $\mathrm{O}_{3}, \mathrm{CO}, \mathrm{NO}_{\mathrm{y}}$, and relative humidity. About $4 \mathrm{~h}$ later, these relative maxima are observed at $2.2 \mathrm{~km}$ altitude (Fig. 14b) showing that the layer has been captured within the PBL during its diurnal development. In backward mode for FLEXPART runs, particles were initialized in these layers and then being regrouped in 5 clusters along backward trajectories. For both profiles, results show that one of the clusters has passed over Portugal (Fig. 15). Although these results do not constitute a definitive evidence that Portuguese forest fires have polluted the PBL over Frankfurt, they support this hypothesis and challenge modellers to tackle this issue.

\section{Conclusions}

Commercial aircraft measurements of ozone, carbon monoxide and nitrogen oxide from the MOZAIC programme over Frankfurt (Germany) have been investigated during the strong heat wave that hit Europe in the first half of August 2003. The 11-year MOZAIC climatology is used to evaluate the anomalies of thermo-dynamical and chemical parameters. Differences between the heat wave period (2-14 August) and the periods before (16-31 July) and after (1631 August) were highlighted according to the evolution of the meteorological situation. In early August, Europe was under strong anticyclonic conditions which diverted the westerlies to the North. The two weeks of the heat wave presented different air mass circulation associated with the movement of an extratropical low around the anticyclone centre, bringing Saharan and Portuguese air into northern Europe. After this episode, stagnant anticyclonic conditions prevailed. Temperature anomalies during the heat wave were found throughout the troposphere with values greater than climatology by $7^{\circ} \mathrm{C}$ in the lower troposphere and by $3.5^{\circ} \mathrm{C}$ in the mid- and upper-troposphere. Anomalies of wind speed (-30\%) and of relative humidity $(-25 \%)$ stand throughout the troposphere.

This situation allows the emergence of extremely favourable conditions to ozone formation over Europe. In addition to the basic condition due to anthropogenic emissions of ozone precursors, favourable conditions include the extended residence time of air parcels in the boundary layer, a reduction in surface dry deposition due to the drought (Vautard et al., 2005 and Solberg et al., 2008), and eventual additional contributions from enhanced biogenic isoprene 

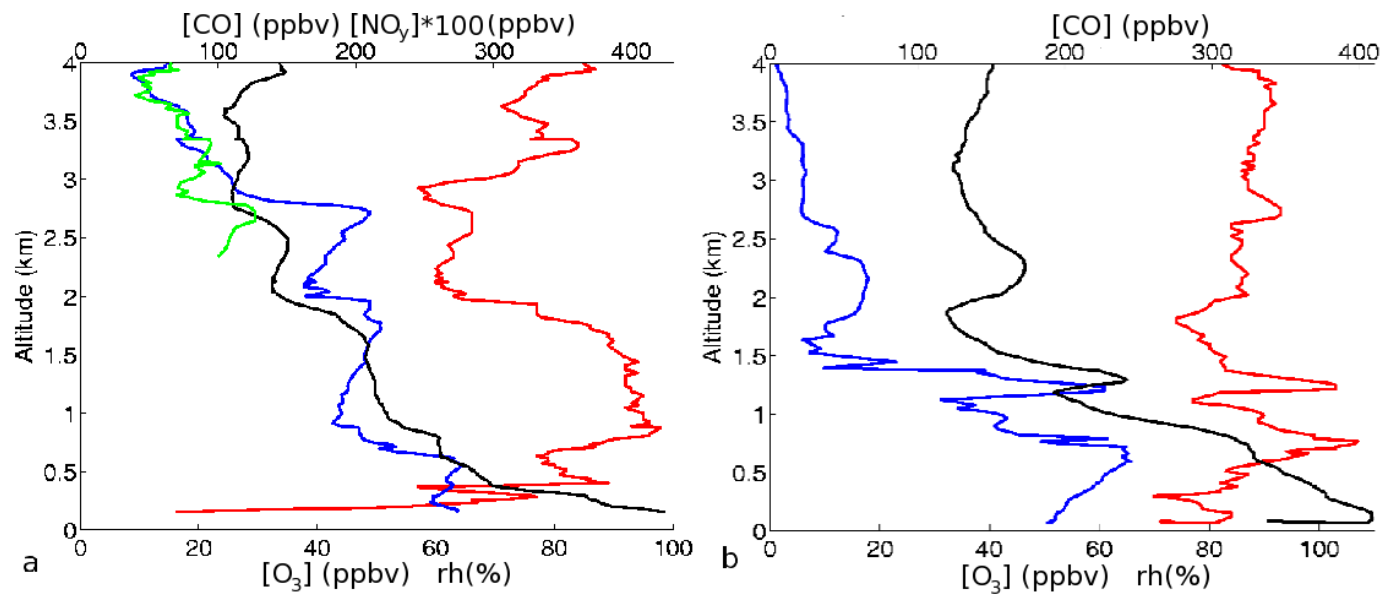

Fig. 14. MOZAIC profiles in Frankfurt, (left) on 10 August 2003 04:46:00 UTC and (right) on 10 August 2003 08:34:00 UTC. Top axis: $\mathrm{CO}$ mixing ratio (ppbv, black) and $100 \times \mathrm{NO}_{\mathrm{y}}$ mixing ratio (green, ppbv); Bottom axis: ozone mixing ratio (ppbv, red) and relative humidity $(\%$, blue).

emissions over France and Germany and from biomass burning emissions from Portuguese fire forests (Solberg et al., 2008). For the first time, the present study gives access to a thorough description of the vertical structure of the pollutants thanks to the MOZAIC programme. Compared to the MOZAIC climatology, ozone observations in Frankfurt during the heat wave present strong anomalies within the planetary boundary layer. At night-time and early morning, the residual layer at $1 \mathrm{~km}$ altitude is composed of a peak anomaly of about $+30 \mathrm{ppbv} \mathrm{O}_{3}$ (peak absolute value of $80 \mathrm{ppbv})$. This anomaly collapses in the surface layer due to the accumulated surface deposition during the night and of the fast ozone titration by NO aircraft traffic emissions in the early morning near the Frankfurt airport. During the day, the entire planetary boundary layer is filled with an average ozone anomaly of about +40 ppbv $\mathrm{O}_{3}$ (peak absolute value 90 ppbv). The $\mathrm{CO}$ measurements show chemically active biomass burning plumes in the mid- and upper-troposphere with origins over Portugal. CO observations overpass the climatology from $90 \mathrm{ppbv}$ at the surface to $40-50 \mathrm{ppbv}$ at $4 \mathrm{~km}$ altitude. During the passage of the extratropical cyclone in the heart of the heat wave period, the change of air masses and the lowering of the top of the planetary boundary layer reduces the height of the ozone polluted layer and allows biomass burning plumes to descend further down in the lower troposphere. The ozone and $\mathrm{CO}$ anomalies reach their greatest vertical extension up to $6 \mathrm{~km}$ altitude at the end of the heat wave period. The availability of frequent MOZAIC profiles during this episode has highlighted the extreme usefulness of routine aircraft observations for environmental monitoring. Efforts to stand out a durable infrastructure from the initial research project MOZAIC are pursued in the European project IAGOS (In-service Aircraft for a Global Observing System European Research Infrastructure, http://www.fz-juelich.de/icg/icg-2/iagos).

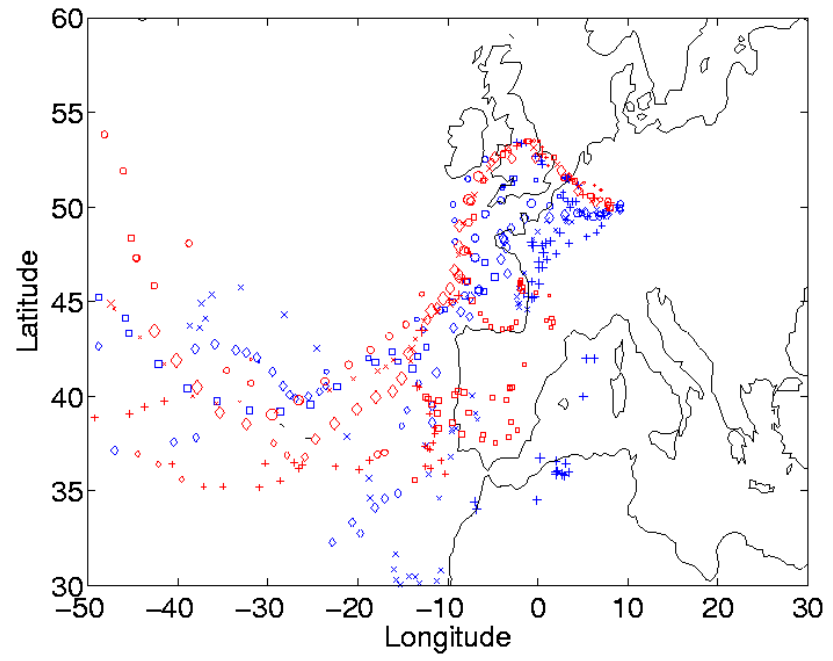

Fig. 15. Positions of FLEXPART clusters of trajectory particles initialized in 10-day backward simulations in CO layers observed on MOZAIC flights displayed on Fig. 14 (see text for details). Blue symbols are for 10 August 2003, 04:46:00 UTC flight, red ones are for 10 August 2003, 08:34:00 UTC flight). Over Portugal, clusters are 5 to 6 days old.

Lagrangian simulations of the transport of anthropogenic $\mathrm{CO}$ emissions from European and North American source regions and of biomass burning $\mathrm{CO}$ emissions from the equivalent area of $0.3 \times 10^{6}$ ha burnt over Portugal were performed in order to compare the relative contributions of source regions to the $\mathrm{CO}$ observations in the planetary boundary layer over Frankfurt. Results show the predominant contribution of European source regions (30\%) to the CO levels for the whole heat wave. Averaged contribution of fires is stronger (35\%) but emissions affect $\mathrm{CO}$ above Frankfurt levels only 
after 6 August 2003. The general concordance in time between the contribution of biomass-burning origin $\mathrm{CO}$ and the largest MOZAIC CO anomaly, as well as the emission sensitivity distributions calculated from backward Lagrangian simulations initialised along MOZAIC CO anomalies, confirm the validity of the questioning about an additional impact of Portuguese forest fires on the pollution level over Frankfurt. This challenge for modellers is being tackled in the European GEMS project (Global Earth-system Modelling using Space and in-situ data, (http://www.ecmwf.int/ research/EU_projects/GEMS/).

Acknowledgements. This work was funded by the French national program LEFE-CHAT (Les Enveloppes Fluides et l'Environnement - Chimie Atmosphérique) from INSU-CNRS (Institut National des Sciences de l'Univers - Centre National de la Recherche Scientifique). M. Tressol is supported by EADS Grant from the fondation of the European Aeronautic Defence and Space Company. The authors acknowledge for the strong support of the European Commission, Airbus, and the Airlines (Lufthansa, Austrian, Air France) who carry free of charge the MOZAIC equipment and perform the maintenance since 1994. MOZAIC is presently funded by INSU-CNRS, Meteo-France, and FZJ (Forschungszentrum Jülich, Germany).

Edited by: P. Monks

\section{References}

Barbosa, P., Libertà, G., and Schmuck, G.: The European Forest Fires Information System (EFFIS) results on the 2003 fire season in Portugal by the 20th of August, European Commmission Report, Directorate General Joint Research Centre, Institute for Environment and Sustainability, Land Management Unit, 2003.

Beniston, M.: The 2003 heat wave in Europe: A shape of things to come? An analysis based on Swiss climatological data and model simulations, Geophys. Res. Lett., 31, L02202, doi: 10.1029/2003GL018857, 2004.

Bessemoulin, P., Bourdette, N., Courtier, P., and Manach, J.: La canicule d'août 2003 en France et en Europe, La météorologie, 46, 25-33, 2004.

Cooper, O. R., Stohl, A., Eckhardt, S., Parrish, D. D., Oltmans, S. J., Johnson, B. J., Nedelec, P., Schmidlin, F. J., Newchurh, M. J., Kondo, Y., and Kita, K.: A springtime comparison of tropospheric ozone and transport pathways on the east and west coasts of the United States., J. Geophys. Res., 110, D05S90, doi: 10.1029/2004JD005183, 2005.

Cros, S., Lefevre, M., Albuisson, M., and Wald, L.: From meteorological satellite data to solar radiation climatological products: the helioclim database, Geophys. Res. Abstr., 6, 03853, 2004.

Damoah, R., Spichtinger, N., Forster, C., James, P., Mattis, I., Wandinger, U., Beirle, S., Wagner, T., and Stohl, A.: Around the world in 17 days-hemispherical-scale transport of forest fire smoke from Russia in May 2003., Atmos. Chem. Phys., 4, 13111321, 2004,

http://www.atmos-chem-phys.net/4/1311/2004/.

ECMWF: User Guide to ECMWF products 2.1, ECMWF Reading, UK, 1995.
Elias, T., Silva, A. M., Belo, N., Pereira, S., Formenti, P., Helas, G., and Wagner, F.: Aerosol extinction in a remote continental region of the Iberian Peninsula during summer, J. Geophys. Res., 111, D14204, doi:10.1029/2005JD006610, 2006.

Elichegaray, C., Colosio, J., and Bouallala, S.: Premier bilan de La pollution photochimique observée en France aucours de l'été 2003, Tech. Rep., ADEME Département Air, 2003.

Emission Inventory Guidebook, 2006: EMEP/CORINAIR Emission Inventory Guidebook, Tech. Rep., 2006.

Emmanuel, K. A. and Živković-Rothman, M.: Development and evaluation of a convection scheme for use in climate models, J. Atmos. Sci, 56, 1766-1782, 1999.

Fiala, J., Cernikovsky, L., de Leeuw, F., and Kurfuerst, P.: Air pollution by ozone in Europe in summer 2003. Overview of exceedances of EC ozone threshold values during the summer season April-August 2003 and comparisons with previous years, Tech. Rep., EEA Topic report, 2003.

Fisher, E., Seneviratne, S., Vidale, P. L., Lüthi, D. and Schär, C.: Soil moisture - atmosphere interactions during the 2003 European summer heatwave, Geophys. Res. Abstr., 8, 05985, 2006.

Forster, C., Wandinger, U., Wotawa, G., James, P., Mattis, I., Althausen, D., Simmonds, P., O’Doherty, S., Gerard Jennings, S., Kleefeld, C., Schneider, J., Trickl, T., Kreipl, S., Jäger, H., and Stohl, A.: Transport of boreal forest fire emissions from Canada to Europe, J. Geophys. Res., 106, 22 887-22 906, 2001.

Fromm, M., Alfred, J., Hoppel, K., Hornstein, J., Bevilacqua, R., Shettle, E., Servranckx, R., Li, Z., and Stocks, B.: Observations of boreal forest fire smoke in the stratosphere by POAM, SAGE II, and lidar in 1998, Geophys. Res. Lett., 27, 1407-1410, 2000.

García, R., Prieto, L., Díaz, J., Hernández, E., and del Teso, T.: Synoptic condition leading to extremely high temperatures in Madrid, Ann. Geophys., 20, 237-245, 2002, http://www.ann-geophys.net/20/237/2002/.

García-Herrera, R., Díaz, J., Trigo, R. M., and Hernández, E.: Extreme summer temperatures in Iberia : health impacts and associated synoptic conditions, Ann. Geophys., 23, 239-251, 2005, http://www.ann-geophys.net/23/239/2005/.

Giglio, L.: Technical note: MODIS collection 4 active fire product user's guide version 2.3, 2007.

Grazzini, F., Ferranti, L., Lalaurette, F., and Vitart, F.: The exceptional warm anomalies of summer 2003, ECMWF Newsletters, 99, 2-8, 2003.

Griffin, R. J., Chen, J., Carmody, K., Vutukuru, S., and Dabdub, D.: Contribution of gas phase oxidation of volatile organic compounds to atmospheric carbon monoxide levels in two areas of the United States, J. Geophys. Res., 112, D10S17, doi: 10.1029/2006JD007602, 2007.

Helten, M., Smit, H. G. J., Sträter, W., Kley, D., Nedelec, P., Zöger, M., and Busen, R.: Calibration and performance of automatic compact instrumentation for the measurement of relative humidity from passenger aircraft, J. Geophys. Res., 103, D19, pp. 25 643-25 652, 1998.

Hodzic, A., Vautard, R., Chepfer, H., Goloub, P., Menut, L., Chazette, P., Deuzé, J.-L., Apituley, A., and Couvert, P.: Evolution of aerosol optical thickness over Europe during the August 2003 heat wave as seen from CHIMERE model simulations and POLDER data, Atmos. Chem. Phys., 6, 1853-1864, 2006, http://www.atmos-chem-phys.net/6/1853/2006/.

Hodzic, A., Madronich, S., Bohn, B. Massie, S., Menut, L., and 
Wiedinmyer, C.: Wildfire particulate matter in Europe during summer 2003: meso-scale modeling of smoke emissions, transport and radiative effect., Atmos. Chem. Phys., 7, 4043-4064, 2007 ,

http://www.atmos-chem-phys.net/7/4043/2007/.

Immler, F., Engelbart, D., and Schrems, O.: Fluorescence from atmospheric aerosol detected by a lidar indicates biogenic particles in the lowermost stratosphere, Atmos. Chem. Phys., 5, 345-355, 2005 , http://www.atmos-chem-phys.net/5/345/2005/.

Kalnay, E., Kanamitsu, M., Kistler, R., Collins, W., Deaven, D., Gandin, L., Iredell, M., Saha, S., White, G., Woollen, J., Zhu, Y., Chelliah, M., Ebisuzaki, W., Higgins, W., Janowiak, J., Mo, K. C., Ropelewski, C., Wang, J., Leetmaa, A., Reynolds, E., Jenne, R., and Joseph, D.: The NCEP/NCAR 40-year reanalysis project., B. Am. Meteorol. Soc., 77, 437-471, 1996.

Labonne, M., Bréon, F.-M., and Chevallier, F.: Injection height of biomass burning aerosols as seen from a spaceborn lidar., Geophys. Res. Lett., 34, L11806, doi:10.1029/2007GL029311, 2007.

Lee, J. D., Lewis, A. C., Monks, P. S., Jacob, M., Hamilton, J. F., Hopkins, J. R., Watson, N. M., Saxton, J. E., Ennis, C., Carpenter, L. J., Carslaw, N., Fleming, Z., Bandy, B. J., Oram, D. E., Penkett, S. A., Slemr, J., Norton, E., Rickard, A. R., Whalley, L. K., Heard, D. E., Bloss, W. J., Gravestock, T., Smit, S. C., Stanton, J., Pilling, M. J., and Jenkin, M. E.: Ozone photochemistry and elevated isoprene during the UK heatwave of August 2003, Atmos. Environ., 40, 7598-7613, 2006.

Luterbacher, J., Dietrich, D., Xoplaki, E., Grosjean, M., and Wanner, H.: European seasonal and annual temperature variability, trends, and extremes since 1500, Science, 303, 1499-1503, 2004.

Lyamani, H., Olmo, F. J., Alcántara, A., and Alados-Arboledas, L.: Atmospheric aerosols during the 2003 heat wave in southeastern Spain I: Spectral optical depth, Atmos. Environ., 40, 6453-6464, 2006a.

Lyamani, H., Olmo, F. J., Alcántara, A., and Alados-Arboledas, L.: Atmospheric aerosols during the 2003 heat wave in southeastern Spain II: Microphysical columnar properties and radiative forcing, Atmos. Environ., 40, 6465-6476, 2006b.

Marenco, A., Thouret, V., Nedelec, P., Smit, H., Helten, M., Kley, D., Karcher, F., Simon, P., Law, K., Pyle, J., Poschmann, G., Von Wrede, R., Hume, C., and Cook, T.: Measurement of ozone and water vapour by Airbus in-service aircraft: The MOZAIC airborne program, An overview, J. Geophys. Res., 103, 25 631$25642,1998$.

Narayana Rao, T., Kirkwood, S., Arvelius, J., von der Gathen, P., and Kivi, R.: Climatology of UTLS ozone and the ratio of ozone and potential vorticity over northern Europe, J. Geophys. Res., 108, D22, doi:10.1029/2003JD00386, 2003.

Nedelec, P., Cammas, J.-P., Thouret, V., Athier, G., Cousin, J.-M., Legrand, C., Abonnel, C., Lecoeur, F., Cayez, G., and Marizy, C.: An improved infra-red carbon monoxide analyser for routine measurements aboard commercial Airbus aircraft: Technical validation and first scientific results of the MOZAIC program, Atmos. Chem. Phys., 3, 1551-1564, 2003, http://www.atmos-chem-phys.net/3/1551/2003/.

Olivier, J., Berdowski, J., Peters, J., Bakker, J., Visschedijk, A., and Bloos, J.: Applications of EDGAR. Including a description of EDGAR 3.2: reference database with trend data for 1970-1995, RIVM report 773301001/NRP report 410200 051, 2002.
Ordonez, C., Mathis, H., Furger, M., Henne, S., Hüglin, C., Staehelin, J., and Prévôt, A. S. H.: Changes of daily surface ozone maxima in Switzerland in all seasons from 1992 to 2002 and discussion of summer 2003, Atmos. Chem. Phys., 5, 1187-1203, 2005 , http://www.atmos-chem-phys.net/5/1187/2005/.

Pace, G., Meloni, D., and di Sarra, A.: Forest fire aerosol over the Mediterranean basin during summer 2003, J. Geophys. Res., 110, D21202, doi:10.1029/2005JD005986, 2005.

Pätz, H.-W., Volz-Thomas, A., Hegglin, M. I., Brunner, D., Fischer, H., and Schmidt, U.: In-situ comparison of the $\mathrm{NO}_{\mathrm{y}}$ instruments flown in MOZAIC and SPURT, Atmos. Chem. Phys., 6, 24012410, 2006, http://www.atmos-chem-phys.net/6/2401/2006/.

Pfister, G., Pétron, G., Emmons, L. K., Gille, J. C., Edwards, P. D., Lamarque, J.-F., Attie, J.-L., Granier, C., and Novelli, P. C.: Evaluation of $\mathrm{CO}$ simulations and the analysis of $\mathrm{CO}$ budget for Europe., J. Geophys. Res., 109, D19304, doi:10.1029/ 2004JD004691, 2004.

Pison, I. and Menut, L.: Quantification of the impact of aircraft traffic emissions on tropospheric ozone over Paris area., Atmos. Environ., 38, 971-983, 2004.

Real, E., Law, K. S., Weinzier, B., Fiebig, M., Petzold, A., Wild, O., Methven, J., Arnold, S., Stohl, A., Huntrieser, H., Roiger, A., Schlager, H., Stewart, D., Avery, M., Sachse, G., Browell, E., Ferrare, R., and Blake, D.: Processes influencing ozone levels in Alaskan forest fire plumes during long-range transport over the North Atlantic, J. Geophys. Res., 112, D10S41, doi:10.1029/ 2006JD007576, 2007.

Roelofs, G. J. and Lelieveld, J.: Model analysis of stratospheretroposphere exchange of ozone and its role in the tropospheric ozone budget, in book Chemistry and Radiation in the ozone layer, 25-44, 2000.

Schär, C., Lüthi, D., Beyerle, U., and Heise, E.: The soil precipitation feedback: a process study with a regional climate model, J. Climate, 12, 722-741, 1999.

Schär, C., Vidale, P. L., Lüthi, D., Frei, C., Häberli, C., Liniger, M. A., and Appenzeller, C.: The role of increasing temperature variability in European summer heatwaves, Nature, 427, 332336, 2004.

Seibert, P.: Parametrisation of convective mixing in a Lagrangian particle dispersion model, Proceedings of the 5th GLOREAM Workshop, Wengen (CH), 24-26 September 2001.

Sillman, S. and Samson, P. J.: Impact of temperature on oxidant photochemistry in urban, polluted rural and remote environments, J. Geophys. Res., 100, 11497-11 508, doi:10.1029/ 2005JD005986, 1995.

Solberg, S., Hov, Ø., Søvde, A., Isaksen, I. S. A., Coddeville, P., De Backer, H., Forster, C., Orsolini, Y., and Uhse, K.: European surface ozone in the extreme summer 2003, J. Geophys. Res., 113, D07307, doi:10.1029/2007JD009098, 2008.

Stohl, A. and Thomson, D. J.: A density correction for Lagrangian particle dispersion models, Bound.-Lay. Meterol., 90, 155-167, 1999.

Stohl, A., Hittemberg, M., and Wotawa, G.: Validation of the Lagrangian dispersion model FLEXPART against large scale tracer experiment data, Atmos. Environ., 32, 4245-4264, 1998.

Stohl, A., Spichtinger-Rakowsky, N., Bonasoni, P., Feldmann, H., Memmesheimer, M., Scheel, H. E., Trickl, T., Hübener, S., 
Ringer, W., and Mandl, M.: The influence of stratospheric intrusions on alpine ozone concentrations., Atmos. Environ., 34, 1323-1354, 2000.

Stohl, A., Forster, C., Frank, A., Seibert, P., and Wotawa, G.: Technical note: The Lagrangian particle dispersion model FLEXPART version 6.2, Atmos. Chem. Phys., 5, 2461-2474, 2005, http://www.atmos-chem-phys.net/5/2461/2005/.

Thouret, V., Marenco, A., Logan, J. A., Nedelec, P., and Grouhel, C.: Comparisons of ozone measurements from the MOZAIC airborne program and the ozone sounding network at eight locations, J. Geophys. Res., 103, 25 695-25 720, 1998.

Trigo, R. M., García-Herrera, R., Diaz, J., and Trigo, I. F.: How exceptional was the early August 2003 heatwave in France?, Geophys. Res. Lett., 32, L10701, doi:10.1029/2005GL022410, 2005.
Vautard, R., Honoré, C., Beekmann, M., and Rouil, L.: Simulation of ozone during the August 2003 heat wave and emission control scenarios, Atmos. Environ., 39, 2957-2967, 2005.

Vautard, R., Yiou, P., D'Andrea, F., de Noblet, N., Viovy, N., Cassou, C., Polcher, J., Ciais, P., Kageyama, M., and Fan, Y.: Summertime European heat and drought waves induced by wintertime Mediterranean rainfall deficit, Geophys. Res. Lett., 34, L07711, doi:10.1029/2006GL028001, 2007.

Volz-Thomas, A., Berg, M., Heil, T., Houben, N., Lerner, A., Petrick, W., Raak, D., and Pätz, H.-W.: Measurements of total odd nitrogen (NOy) aboard MOZAIC in-service aircraft: instrument design, operation and performance., Atmos. Chem. Phys., 5, 583-595, 2005,

http://www.atmos-chem-phys.net/5/583/2005/. 